Competition and Firm Performance: Lessons from Russia

\author{
By: J. David Brown and John S. Earle
}

Working Paper Number 296

March 2000 


\title{
Competition and Firm Performance: Lessons from Russia
}

\author{
March 24, 2000 \\ J. David Brown \\ SITE, CEPR \\ John S. Earle \\ SITE, CEU
}

\begin{abstract}
The "big-bang" liberalization of the inefficient Russian economy in 1992 provides a fruitful setting for analyzing the impact of several dimensions of market competition and other factors on enterprise efficiency. We analyze 1992-1998 panel data on 14,961 enterprises covering 75 percent of industrial employment, emphasizing the varied sources, geographic scope, intensity, time path, and survival effects of competitive pressures. We find large, positive effects on TFP from competition in domestic product and local labor markets, and from imports and better transportation infrastructure, although the first effect appears only gradually. Non-state firms outperform state enterprises, even after correction for selection bias.

JEL Classifications: D24, D4, J42, L1, L33, P23, P31
\end{abstract}

Keywords: competition, firm exit, foreign trade, monopsony, privatization, Russia, and total factor Productivity.

Stockholm Institute of Transition Economics, Stockholm School of Economics, Box 6501, S-113 83 Stockholm SWEDEN; +46 8316422 fax; email and phone for David Brown: David.Brown@hhs.se and +46 8 736-9685; email and phone for John Earle: John.Earle@ hhs.se and +468 736-9680.

We wish to thank Yuri Andrienko, Michael Barz, Evgenia Bessonova, Sergiy Biletsky, Elizaveta Brazdnikova, Annette Brown, Maria Gorban, Dennis Karpov, Stanislav Kolenikov, Maria Lopukhova, Elena Paltseva, Mikhail Sulyaev, Igor Tchekhov, and Staffan Westersträn for invaluable assistance in assembling the database. We also gratefully acknowledge financial support from ACE-TACIS Grant 
No. T95-4115-R, the MacArthur Foundation, The Bank of Sweden Jubileum Fond, and the Jan Wallander and Tom Hedelius Foundation. 


\section{Non-Technical Summary}

Weaned on models of competitive equilibrium, economists instinctively tend to invoke the virtues of competition in a wide variety of situations. But this usually unreflective appeal to competitive forces has received remarkably little empirical testing and verification, and even when it has been tested, the evidence has been rather weak. We speculate that the paucity of empirical support is a result of the difficulty of observing these forces at work in equilibrium, or at least in the rather stable conditions of most economies in which such studies have been conducted.

In this paper, we exploit the quasi-experiment offered by the Russian economy in transition to avoid the endogeneity problems that plague other analyses and to observe the potentially large efficiency effects that may be present in enterprises inherited from the socialist period. Our analysis embraces a variety of dimensions of competitive pressure, including not only domestic market structure at the national level, but also import competition, regional variation of product markets, transportation infrastructure, and labor market competition. We study the time path of the impact of a competitive shock - the abrupt liberalization of prices, entry, imports, and labor mobility - in January 1992, and examine non-linearities in the effect of each of these competitive forces. Our data set permits us to investigate virtually any measure of product market competition that has been proposed, and our results are strongly robust across alternative specifications.

We first test for determinants of firm survival, finding that foreign and domestic product market competition and good transportation infrastructure have a negative effect on survival, consistent with competition being a screening device. Demand shocks have the expected effects: industry and regional growth and relative price changes all increase the probability of survival. Initial conditions also matter, as higher initial profitability, exporting activity, and size increase the probability of survival, while military-industrial complex affiliation lowers it. Foreign joint venture and 100 percent private ownership lowers the probability of survival relative to other ownership types.

The total factor productivity results provide strong evidence that domestic product market competition, import competition, and local labor market competition have strong positive effects on efficiency. The impact of liberalization appears only gradually in the domestic product market, taking about four years to attain about 90 percent of the long-run value, but we find no such lags with respect to import competition or labor market competition. Domestic product market and labor market competition show increasing marginal effects, while the marginal effect of import competition is decreasing. Local product market competition has a greater effect on efficiency than national competition, suggesting that markets are geographically segmented. Former members of Soviet-era production associations appear to be competing with one another rather than colluding. Better transport infrastructure appears to turn potential product market competition into actual competition, while at the same time reducing firms' monopsony power on the labor market by facilitating worker mobility across municipalities.

Our results suggest that downsizing firms have more difficulty maintaining productivity in industries and regions with more negative demand shocks. Positive price shocks appear to have cushioned firms from having to adjust. Initial conditions are significant as well; higher initial profitability and being an exporter raise productivity, while the extent of exporting activity and military-industrial complex affiliation lower it. We also find that non-state firms outperform state enterprises, even after controlling for selection bias in the determination of ownership.

The results have implications for industrial policy. A reduction in import barriers and geographic market segmentation, the latter accomplished through investment in transportation infrastructure and elimination of interregional administrative trade barriers, should stimulate industrial productivity. 


\section{Introduction}

Although the virtuous consequences of competitive product and factor markets for enterprise efficiency are fundamental tenets in most economists' thinking, the empirical case for these beliefs is relatively weak. Most empirical studies of firm and industry performance have focussed on some measure of profitability as the outcome variable, rather than efficiency, but there is little necessary connection between the two. The relatively few studies examining efficiency have mostly produced rather weak results with respect to the effects of competition, and they have been hampered by data and identification problems.

One line of inquiry has analyzed firms or industries in developed capitalist economies and undertaken static, cross-section comparisons of operating performance or productivity across observations with fixed market environments (e.g., Vining and Boardman, 1992; Blanchflower and Machin, 1996; Berger and Hannan, 1998). Such studies, while informative, face difficulties in controlling for unobserved heterogeneity and the possible endogeneity of market structure. Demsetz (1973) and Peltzman (1977) argue, for instance, that market structure is endogenous in that better performance of some firms may lead to higher concentration, so that there is no necessary relationship between the two variables in a cross-section.

A second type of investigation has used panel data to identify the impact of variables of interest on firm efficiency through their intertemporal changes (e.g., Nickell, 1996). A problem with these studies is that data availability has typically limited them to examine only small numbers of firms spread across a wide variety of industries. In the stable economies of the West, there have been few opportunities to analyze firms that have undergone substantial changes in their market environments, particularly large numbers of firms undergoing diverse experiences of such changes simultaneously.

A final problem with most of the studies is that the potential efficiency gains due to competition that may be observable by the researcher are rather small, insofar as most of the economies where such studies are undertaken are dominated by "workably competitive" markets, so that the general environment may still exert a disciplining force even if the particular conditions facing the firm do not. Natural monopolies in the West, after all, usually operate in competitive markets for managers, labor, and most other factors; they can avail themselves of the latest technologies, organizational innovations, and managerial techniques; their performance can be compared at least along some dimensions with neighboring competitive firms; and instances of gross malfeasance can be publicly evaluated and remedied through a democratic process. All of these factors would seem to go quite some distance towards mitigating inefficiencies associated with monopoly power.

The situation in Russia, the testing ground for this paper, stands in stark contrast. Russia's "product market structure" at the beginning of the transition was determined by decisions that had been made by Soviet central planners rather than by market forces. Those decisions were motivated to a considerable extent by the need to monitor and control the production units and by political considerations, which tended to skew choices of location, scale and integration; economic efficiency was frequently secondary. ${ }^{-}$Moreover, prices and wages were controlled, output quantities and types were set by plan, sales were virtually guaranteed, soft budget constraints prevented bankruptcy, and firms could grow (or shrink) only by order of the central authority. Although there is some debate over the extent to which the planning system resulted in monopolized or highly concentrated sectors, it is clear that the Soviet fystem, relative to market economies, had very few small firms and very low rates of entry and exit.

This ossified industrial organization was suddenly liberalized on January 1, 1992, when prices, foreign trade, supply arrangements, labor mobility and the entry of new businesses were simultaneously freed. Where before there was little or no effective competition in any product or factor markets, suddenly Russian firms were forced to compete with each other and with new foreign competitors, while demand became more fickle and budget constraints became harder. Thus, Russia presents an unusual quasi-experiment where we may test whether an exogenously determined market

\footnotetext{
${ }^{1}$ Kornai (1992) provides a detailed discussion of the goals of central planners, including the implications concerning some aspects of industrial structure.

2 Joskow, Schmalensee, and Tsukanova (1994); Brown, Ickes, and Ryterman (1994); and Brown and Brown (1999)
} 
structure has an effect on firm efficiency. We may also examine the time pattern of adjustment to the liberalization shock: how quickly the increased competition may have improved enterprise productivity.

The shock of liberalization was not only unexpected, but it also hit a set of enterprises that had been operating far from the production frontier when the "big bang" policies took effect. The plant and equipment, labor force, managerial skills, organizational capital, and modes of operating of these firms were built up during a period when there was nothing approaching a competitive market environment, essentially no private ownership, and efficiency and profits were not primary objectives. After the competitive shock hit, therefore, Russian firms have the potential to exhibit large changes as they restructure along many dimensions and re-orient their objectives from the state towards the market. For the researcher, the situation holds out the possibility for observing substantial differences in behavior.

Some peculiarities of Russian geography suggest that it may be fruitful to investigate some regional dimensions of market structure. By far the largest country in the world, Russia is characterized by widely scattered industries frequently separated by vast distances and connected by poor infrastructural networks. While the possibility that product market scope should be defined by region as well as industry has been considered in research on U.S. market structure (e.g., Weiss and Pascoe, 1986), the distances and transport and communication costs appear to pose much greater obstacles to unifying markets in Russia.

The geographic argument also has implications for factor markets, in particular for labor. While in principle it is clear that monopsony power may create slack that permits $\mathrm{x}$-inefficiency precisely analogously to the slack under monopoly power, there have been no empirical studies of the relationship, possibly due to the fact that Western economies show rather little labor market concentration (Boal and Ransom, 1997). Concentrated labor markets - in the limit, one-company towns - are much more common in Russia, suggesting the possibility that monopsony power may indeed be a significant factor in cushioning firm behavior.

A small number of other studies have examined the impact of competition in Russia and other transitional economies, but the research on which we now report has several distinct advantages in terms of the size and coverage of the data set, the time span of observations on each firm, and the availability of a variety of measures of market structure and competition. The work of Earle and Estrin (1995 and 1998), for instance, relied on a survey of about 200 firms (with complete information) carried out in July 1994, which was not long after the competitive shock, their measures of product market concentration were highly aggregated - as were their indicators of import penetration - and their data did not permit them to estimate total factor productivity. Perhaps these data limitations explain their finding that competition appeared to have little role in accounting for enterprise performance as of mid-1994, although they did find suggestive patterns associated with the geographic scope of product markets - which we follow up in this paper. In a study of 211 Mongolian enterprises, Anderson, Lee, and Murrell (1999) find strong effects of competition, certainly much larger than in studies of Western economies such as Nickell (1996) and Berger and Hannan (1998). Unfortunately, however, the data in the Mongolian study span only a short period after liberalization finished, the measure of competition/concentration is limited to the firm's (imputed) market share (based on managers' reports) at the end of that period, and the data do not permit an examination of other aspects of competition. Jones, Klinedinst, and Rock (1998) use market share as the concentration measure in the firm's industry in a study of TFP in 247 Bulgarian enterprises, and Konings (1997) relies on qualitative measures from a survey of managers in 346 Bulgarian, Hungarian, and Romanian companies. Li (1997, Table 2) provides estimates of the impact on TFP growth of the ratio of output price growth to material input price growth (a proxy for change in market power) for 272 Chinese enterprises.

By contrast, the panel data set we use for estimation purposes is quite comprehensive, including 75 percent of total employment in Russian industry in 1992, the year of the liberalization

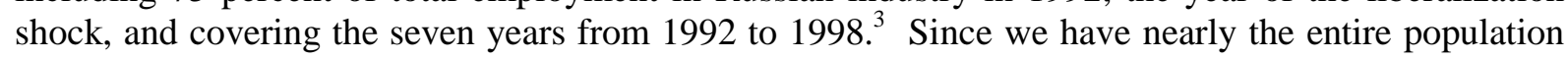

\footnotetext{
${ }^{3}$ Some enterprises are excluded from the regression analysis due to missing values or because they have fewer than 100 employees. The percentage of total industrial employment included in the database in 1993 that is used
} 
of medium- and large-size industrial enterprises, including information on their exact locations and disaggregated five-digit industries, we can use much more precise measures of market structure than those available to other researchers in Russia or in many other countries. The size and scope of the database, as well as the unusual characteristics of Russia permit us to investigate several geographic dimensions of competitive pressure and to examine competition in local labor markets. Our data also contain useful controls and instruments, and much better and more disaggregated information on import competition than was heretofore available. We use this rich database to trace out the impact of several dimensions of market competition and other factors on firm-level TFP.

In the following section, we develop more fully our motivation for examining a number of dimensions of the relationship between firm efficiency and market competition in Russia. Next, we discuss our econometric framework, data, and measures of key variables. Finally, we present estimation results followed by a conclusion.

\section{Dimensions of the Competition-Efficiency Relationship}

Our basic approach in this paper, as we have suggested above, is to exploit the sudden shock of liberalization in a context where market structure was exogenously determined and where firms might exhibit large differences in behavior. We use our detailed information on the quasiexperimental situation in Russia to investigate a number of particular dimensions of the competitionefficiency relationship. A first set of dimensions concerns geography. While industrial organization analysts and regulatory agencies have devoted much attention to the question of the appropriate definition of the market according to industrial or product classification (e.g., Pittman and Werden, 1990), there has been relatively little research on the implications of geographic segmentation of product markets for enterprise efficiency. Studies such as Weiss (1972) and Scherer et al (1975) have examined the geographic issue for some developed market economies, but their motivation was the impact not on efficiency, but rather on profits. The few empirical studies of the impact of competitive pressures on firm efficiency have tended to focus exclusively on national product market concentration as the variable of interest (Caves and Barton, 1990; Nickell, 1996), although one exception is Berger and Hannan (1998), who define product markets as standard metropolitan statistical areas in their analysis of retail banking.

In this paper, we take a much broader approach to the role of geography in affecting the level of competitive pressure exerted on firms. Our motivation is the tremendous size and uneven infrastructure of Russia, suggesting that product markets may be much more differentiated geographically than in the standard setting. We use our data to measure regional as well as national product market concentration, therefore, but we also try to take into account the fact that the geographic scope of markets is likely to vary according to the nature of the product. For this reason, we construct mixed measures of national and regional product market structure, where the mixing variable is meant to capture the weight attached to each geographic level in the level of competitive pressure.

Foreign competition, which was also abruptly liberalized at the beginning of 1992 , is another dimension of product market pressure. The possibility that imports may function as a disciplinary device, improving firm efficiency, has been studied by a number of authors, including Carlsson (1972); Saunders (1980); Geroski and Jacquemin (1981); DeGhellink, Geroski, and Jacquemin (1988); and Caves and Barton (1990). Although these studies tend to find that there is indeed an import discipline effect, particularly on domestic monopolists, they are open to the criticism that firm efficiency, imports, and domestic competition are all jointly determined. We use the abrupt import liberalization in Russia to disentangle this simultaneity problem, under the argument that the process generating imports in the immediate post-liberalization period was exogenous with respect to the subsequent evolution of Russian enterprise performance. Previous studies of such large events appear to be confined to the impact of imports on profitability (e.g., Esposito and Esposito, 1971; or Geroski, 1982). Import competition may be especially effective in Russia due to the substantial quality deficit of most Soviet-made goods as well as the possibly more elastic supply responsiveness of imports relative to domestic competitors.

for calculating the market structure measures is 91 percent. These figures are calculated by dividing the sum of employment for the firms in our sample by the total industrial employment reported in Goskomstat (1996). 
Another dimension of international markets concerns participation in export markets. There are a number of arguments why exporting firms may perform better than non-exporters. Aw, Chen, and Roberts (1997) argue that international markets may be a tougher screen for sorting out high productivity from low productivity firms. Sabel and Prokop (1996) claim that the discipline of having to conform to a set of international quality standards, rather than competition, corporate governance or other factors, is the prime agent encouraging restructuring. Exporters may also be more potentially viable than non-exporters since they are already producing goods that have a market, consistent with the finding in Repkine and Walsh (1998) that East European enterprises exporting to the European Union have increased output during the transition, while other firms have decreased output. In the standard setting of a stable market economy, the problem with investigating the impact of export orientation is even more acute than with other dimensions of a firm's market environment, as exporting capabilities and decisions are clearly endogenous. Once again, Russia provides a useful quasi-experimental setting for investigating the issue, as export transactions were tightly controlled during the socialist period in Russia, and then liberalized at the same time as were imports.

Previous empirical research on the relationship between competition and firm performance has focussed exclusively on the product market, ignoring factor markets. There Boal and Ransom (1997), in a recent survey of the literature on labor market monopsony, for instance, report no studies of the impact of labor market concentration on efficiency or productivity. Yet market power with respect to some factor of production may worsen incentives for managers just as readily, and for precisely analogous reasons, as power in the product market. Perhaps the lack of research reflects the difficulty in identifying factor markets where concentration is sufficiently high to warrant investigation and where comparisons can readily be drawn with otherwise similar firms facing competitive factor market conditions. Again, Russian geography provides us with an interesting setting for investigating this question, as a considerable number of local labor markets are dominated by a single or small number of employers. Thus, we can exploit the peculiar spatial conditions of Russian markets to estimate the impact of local labor market power on firm performance.

A further aspect of the geography of both product and factor market competition concerns transportation infrastructure. If a firm's regional product market has poor transportation connections, then it will be able to achieve some local monopoly power, just as a firm in a local labor market with poor links to neighboring localities may have local monopsony power. Poor transportation infrastructure functions as a barrier to entry by competitors. The large size and highly variable infrastructure of the Russian Federation suggest that transportation costs may be quite significant for some regions of the country, and that these should be taken into account together with conventional measures of market structure.

The impact of competition on efficiency may vary in the time dimension. In the short run, there may be relatively little that firms can do to restructure and improve their performance, but as they have more time to adjust, the benefits of competition may become more apparent. While much of the theoretical analysis of competition and firm behavior is implicitly cast in the long run, assuming away adjustment costs, there appears to be little or no research that attempts to measure the time path of the effects. We exploit the existence of several years of performance data after the initial competitive shock to trace out the impact on firm behavior - from initial reaction to longer run adjustment.

We are also concerned with the intensity dimension of the competition-efficiency relationship: does the magnitude and perhaps even the direction of the marginal competition effect vary with the level of competition? To start with, while most economists assume that competition tends to improve performance in most circumstances, it is sometimes claimed that the effect may be negative, either because it prevents firms from accumulating rents that can be used for research and development, according to Schumpeter (1950) and Nelson and Winter (1982), or - in the transition context because of the difficulty of financing the high adjustment costs associated with restructuring, according to Ickes, Ryterman, and Tenev (1995). Furthermore, Gaddy and Ickes (1999) argue that firms that are closer to being "competitive" are more likely to restructure than those further away, since the effort needed is smaller.

\footnotetext{
${ }^{4}$ An exception concerns managerial labor markets
} 
The problem with these arguments, however, is that the key variables are not easily observable, and we would add a somewhat different reason for possible non-monotonicity: the difficulties experienced by firms needing to reduce the scale of their operations. Down-sizing may necessitate large-scale layoffs of workers and shedding of assets, both of which may be costly, particularly where workers have contracts or the state pressures firms to maintain employment and where secondary markets for assets function poorly, all of which conditions hold in Russia. Compared to other firms, a firm facing a larger fall in product demand may find it more difficult to maintain productivity. If the liberalization shock was very large for some firms in Russia, in the sense that they need to restructure and downsize, then such firms may exhibit lower productivity. This suggests that the effects of increased competition may be nonmonotonic, positive at low levels but negative at higher ones.

Moreover, the ability of a contracting firm to maintain productivity is also a function of its environment. In regions and industries that are growing more rapidly, a firm hit by a large negative shock will find it easier to reduce employment and to sell its plant and equipment, as factor markets for labor and used capital would be more buoyant compared to an environment of decline. Industrial output has declined steeply in Russia during our sample frame, even more than in most transition economies (Fischer, Sahay, and Vegh, 1996), so these considerations may be important for understanding differences in firm performance. At the same time, they carry lessons for understanding productivity and competition in declining firms and sectors more generally.

A related issue concerns the particularly severe restructuring difficulties faced by the militaryindustrial complex (MIC). Firms in this sector experienced an enormous fall in demand for their military output in the early 1990s, but they have had little success in converting to civilian production (Earle and Komarov, 2000). Perhaps this is not surprising, as defense conversion is a difficult task even in well-functioning economies like that in the United States. But it implies that military firms may have lower productivity, as they cope with the demand shock and particular restructuring difficulties. A counter-argument is that such firms were privileged under the socialist regimes and may have started the transition with better technology than other firms. Which of these effects dominates is an empirical question that we are able to address with our data.

For firms operating far from the production frontier, the real question may involve survival, and indeed one of the most important effects of a sudden increase in competitive pressures may be to drive incumbent firms out of business. Research by Dunne, Roberts, and Samuelson (1989) and others has begun to establish some of the basic patterns in firm births, deaths, and longevity, but the primary focus has been on issues of firm size and life cycle, thus on "normal firm turnover," and there has been no investigation of the impact of competitive shocks on survival probability. This neglect may be partly due to the more general neglect of efficiency effects of competition, but it is also probably a result of data problems: the early work on the competition-performance relationship used industrylevel information and the later work using firm-level data has tended to examine small samples consisting only of surviving firms in relatively stable market economies. Both the empirical setting we investigate - a massive competitive shock on a population of highly inefficient firms - and the comprehensiveness of our data suggest that this issue may be fruitfully addressed. Indeed, the possibility of non-random survival of firms implies that we should take selection bias into account in our estimation procedure.

Finally, competitive forces may be correlated with other variables, which are both necessary to control for and of particular interest in and of themselves. Most obviously, it is possible that industries with less concentrated market structure were more likely to be privatized, as the state withheld natural monopolies and resource sectors from the privatization program. Thus, it would be desirable to analyze patterns of ownership and corporate governance, which have undergone huge changes in Russia during this period (Boycko, Shleifer, and Vishny, 1995; Blasi, Kroumova, and Kruse, 1997; Earle and Estrin, 1997). The data we employ in this paper unfortunately lack very precise measures of these changes, but we are able to distinguish some basic categories of state and private firms, and we control for these variables when examining the impact of our measures of competition. Related to the issue of state ownership is the hardness of the firm's budget constraints, as a variety of types of direct and indirect support for firms continued in Russia through the 1990s (Earle and Estrin, 1998). Softness of the budget constraint, which may also be correlated with market structure, is difficult to measure, unfortunately, but we attempt to control for it using some proxy variables here. 


\section{Econometric Framework}

In estimating the impact of the various dimensions of the competition-efficiency relationship, our method in this paper follows the recent literature on natural and quasi-experiments in economics (Meyer, 1995). We argue that the socialist policies created a different data-generating process for variables representing competititive pressure at the time of liberalization, thus creating some exogenous variation in these factors and alleviating the possible simultaneity bias that besets analyses of market structure in the standard setting of stable market economies. According to the "efficient market structure" view of Demsetz (1973) and Peltzman (1977), for instance, market concentration arises as a result of the growth of more efficient firms, implying that concentration measures may be endogenous when included as regressors in profitability or productivity equations.

Under the Soviet regime, however, central planners determined the size and resources of firms according to the whims of the Communist Party leadership and political criteria such as regional integration, employment, and military considerations (Kornai, 1992). Planners had an incentive also to take efficiency into account (simply to increase their rents), but they faced extraordinary difficulties in measuring firm productivity in an economy of fixed, distorted relative prices and considerable black market activity. Managerial incentives were tied primarily to fulfillment of the output plan targets, and only secondarily to costs (which again were measured using artificial prices). For these reasons, we believe that the process of reverse causality - running from efficiency to market structure - is much attenuated when we study firms and industries emerging from the socialist system. We do control for other confounding influences and various sources of heterogeneity, however, and we take into account sample selection bias working through the survival process.

Concerning the indicator of enterprise performance, the traditional industrial organization literature going back to Bain (1956) has focused on profitability or price-cost margins in relation to measures of competitive pressure (market structure), but our interest in this paper is technical efficiency rather than pricing behavior. The corporate governance literature in the West has been more concerned with efficiency issues and has adopted a number of alternative measures: accounting profits (e.g., Demsetz and Lehn, 1985; Holderness and Sheehan, 1988; Prowse, 1992), abnormal stock price increases (e.g., Wruck, 1989; Smith, 1996), and Tobin's Q (e.g., Morck, Shleifer, Vishny, 1988; McConnell and Servaes, 1990). The literature on private versus state ownership has tended to use accounting measures of profits and revenues, due to the unavailability of stock prices for state-owned firms (e.g., Boardman and Vining, 1989; Megginson, Nash, and Randenbourgh, 1994). Finally, Bhagat and Black (1997) have recently included a variety of firm-value and accounting measures, concluding that some results are non-robust across the alternative performance variables, although the focus of their paper is not the effects of market competition, but rather of board composition.

In the context of the Russian transition, however, such performance indicators are highly questionable, due to problems of both measurability and appropriateness. No reliable measures of firm value are available, as stock markets are just beginning to operate and there are few benchmarks for evaluating the potential of firms. Accounting profits (and price-cost margins) are notoriously unreliable, and furthermore they may reflect market power and monopolistic price-setting as well as efficiency considerations.

Instead, we follow the approach of Nickell (1996) and others (including empirical analyses of the comparative performance of producer cooperatives versus conventional firms - see the summary in Bonin, Jones, and Putterman, 1993), of focusing on disembodied total factor productivity (TFP). We estimate the evolution of the impact of competition on TFP over several years of postliberalization data, controlling for other factors and for selection bias. Our data permit us to estimate an augmented production function with three inputs:

$$
Y=F\left(A, K, L_{1}, L_{2}\right) \text {, }
$$

where $Y$ =value-added, $K=$ capital stock, $L_{I}=$ labor services of type 1 (number of production workers), $L_{2}=$ labor services of type 2 (number of nonproduction workers), and $A$ indexes total factor productivity (disembodied), with

$$
A=A(X, u) \text {, }
$$

where $X$ is a vector of factors affecting managerial and worker incentives in the firm, including those arising from market structure, and $u$ is a disturbance reflecting residual factors affecting productivity. Assuming a translog form for $F$ and an exponential for $A$, (1) can be rewritten as 


$$
\begin{gathered}
\log Y_{i}=\gamma_{0}^{\prime} X_{i}+\gamma_{K} \log K_{i}+\gamma_{1} \log L_{1 i}+\gamma_{2} \log L_{2 i} \\
+\gamma_{K K}\left(\log K_{i}\right)^{2}+\gamma_{11}\left(\log L_{1 i}\right)^{2}+\gamma_{22}\left(\log L_{2 i}\right)^{2} \\
+\gamma_{K 1} \log K_{i} \log L_{1 i}+\gamma_{K 2} \log K_{i} \log L_{2 i}+\gamma_{12} \log L_{1 i} \log L_{2 i}+u_{i}
\end{gathered}
$$

where $\log$ refers to the natural logarithm, $i$ indexes firms and the $\gamma$ are parameters to be estimated, including the vector $\gamma_{0}$ of coefficients on the elements in $X_{i}$. Our measures of $X_{i}$ include national and regional product market competition (Herfindahl-Hirschman index or 2-firm concentration ratio), mixtures of the national and regional measures (with weights given alternatively by the percent of consumer goods in total firm output and by a measure of transportation infrastructure), import penetration, local labor market competition (the HHI for employment in the firm's municipality or rayon), and a measure of transportation infrastructure quality (under the assumption that better transportation infrastructure quality may facilitate product and factor market competition).

Several econometric problems arise in this estimation. One is the possibility that $\mathrm{E}\left(X_{i} u_{i}\right) \neq 0$ due to the endogeneity problems discussed above. In the standard market economy setting, instrumenting $X_{i}$ with lagged values may not adequately address this problem, as there may well be serial correlation in the data-generating process, for instance due to expectations about future market structure. Our argument is that the shock of price and entry liberalization was almost completely unexpected, in the sense that most prior decisions affecting $X_{i 92}$, the value of $X_{i}$ in the year of the shock, 1992, were made without any anticipation that the shock would occur. Furthermore, liberalization can be interpreted as a structural change in $\gamma_{0}$, the impact of $X_{i}$ on productivity. While before liberalization, central planning and monitoring determined the level of productive efficiency, afterwards firms were supposed to compete on the market and to make their own decisions with respect to their output prices, their quantities of production, and their employment of factors of production. Thus, the effect of $X_{i}$ may increase over time.

We implement these ideas using two different methods, which we label the "quasiexperimental" and the "instrumental variables" approach, respectively. Both rely on the use of panel information beginning at the date of liberalization, when we argue that market structure was relatively exogenous. According to the first approach, we fix $X_{i t}=X_{i 92}$ for all $t>92$, where $t$ indexes years (in our data through 1998), and estimate

$$
\begin{gathered}
\log Y_{i t}=\gamma_{0}^{\prime} X_{i 92}+\gamma_{K} \log K_{i t}+\gamma_{1} \log L_{1 i t}+\gamma_{2} \log L_{2 i t} \\
+\gamma_{K K}\left(\log K_{i t}\right)^{2}+\gamma_{11}\left(\log L_{1 i t}\right)^{2}+\gamma_{22}\left(\log L_{2 i t}\right)^{2} \\
+\gamma_{K 1} \log K_{i t} \log L_{1 i t}+\gamma_{K 2} \log K_{i t} \log L_{2 i t}+\gamma_{12} \log L_{1 i t} \log L_{2 i t}+u_{i t} .
\end{gathered}
$$

Under our assumption that $X_{i 92}$ is exogenously determined, $\mathrm{E}\left(X_{i 92} u_{i t}\right)=0$, and estimation of (4) yields consistent estimates of $\gamma_{0}$. As a further check on the robustness of the procedure, we add random effects, permitting individual firm heterogeneity (in the intercept) to vary according to a normal


also permit $\gamma_{0}$ to vary across years:

$$
\begin{gathered}
\log Y_{i t}=\gamma_{03}{ }^{\prime} D_{93} X_{i 92}+\gamma_{04}{ }^{\prime} D_{94} X_{i 92}+\gamma_{05}{ }^{\prime} D_{95} X_{i 92}+\gamma_{06}{ }^{\prime} D_{96} X_{i 92}+\gamma_{07}{ }^{\prime} D_{97} X_{i 92}+\gamma_{08}{ }^{\prime} D_{98} X_{i 92} \\
+\gamma_{K} \log K_{i t}+\gamma_{1} \log L_{1 i t}+\gamma_{2} \log L_{2 i t} \\
+1 / 2 \gamma_{K K}\left(\log K_{i t}\right)^{2}+1 / 2 \gamma_{11}\left(\log L_{1 i t}\right)^{2}+1 / 2 \gamma_{22}\left(\log L_{2 i t}\right)^{2} \\
+\gamma_{K 1} \log K_{i t} \log L_{1 i t}+\gamma_{K 2} \log K_{i t} \log L_{2 i t}+\gamma_{12} \log L_{1 i t} \log L_{2 i t}+u_{i t},
\end{gathered}
$$

where $D_{l}=1$ if the year=t, and 0 otherwise. From the estimates for $\gamma_{03}$ to $\gamma_{08}$, we can trace out the influence of the suddenly exposed competitive climate on enterprise behavior. Following Meyer (1995), we call (4) and (4') the "quasi-experimental" approach because we are treating the 1992 values of the competition variables as though they are exogenous due to their determination by central planners under state socialism.

Our second, "instrumental variables" approach permits $X_{i}$ to vary over time, and is thus more conventional:

$$
\begin{gathered}
\log Y_{i t}=\gamma_{0}^{\prime} X_{i t}+\gamma_{K} \log K_{i t}+\gamma_{1} \log L_{1 i t}+\gamma_{2} \log L_{2 i t} \\
+\gamma_{K K}\left(\log K_{i t}\right)^{2}+\gamma_{11}\left(\log L_{1 i t}\right)^{2}+\gamma_{22}\left(\log L_{2 i t}\right)^{2} \\
+\gamma_{K 1} \log K_{i t} \log L_{1 i t}+\gamma_{K 2} \log K_{i t} \log L_{2 i t}+\gamma_{12} \log L_{1 i t} \log L_{2 i t}+u_{i t} .
\end{gathered}
$$

\footnotetext{
${ }^{5}$ We do not employ fixed effects, both because of the low intertemporal variation in our variables of interest (as we show below) and because of the many unobservable changes in firm boundaries associated with spin-offs, split-ups, and mergers during the transition process.
} 
The problem here is the standard one that $X_{i t}$ is endogenous so that $\mathrm{E}\left(X_{i t} u_{i t}\right) \neq 0$, thus we must take into account the possible endogenous evolution of market structure in a different way. Our method is to treat $X_{i 92}$ as a valid instrument: correlated with $X_{i t}$ but not $u_{i t}$. Random effects are again added to one specification as a robustness check. We can also investigate whether $\gamma_{0}$ varies across years, as firms gradually become more sensitive to competitive forces after the initial shock by permitting it to vary:

$$
\begin{gathered}
\log Y_{i t}=\gamma_{03}{ }^{\prime} D_{93} X_{i t}+\gamma_{04}{ }^{\prime} D_{94} X_{i t}+\gamma_{05}{ }^{\prime} D_{95} X_{i t}+\gamma_{06}{ }^{\prime} D_{96} X_{i t}+\gamma_{07}{ }^{\prime} D_{97} X_{i t}+\gamma_{08}{ }^{\prime} D_{98} X_{i t} \\
+\gamma_{K} \log K_{i t}+\gamma_{1} \log L_{1 i t}+\gamma_{2} \log L_{2 i t} \\
+\gamma_{K K}\left(\log K_{i t}\right)^{2}+\gamma_{11}\left(\log L_{1 i t}\right)^{2}+\gamma_{22}\left(\log L_{2 i t}\right)^{2} \\
+\gamma_{K 1} \log K_{i t} \log L_{1 i t}+\gamma_{K 2} \log K_{i t} \log L_{2 i t}+\gamma_{12} \log L_{1 i t} \log L_{2 i t}+u_{i t},
\end{gathered}
$$

where again we use IV estimation, treating $X_{i 92}$ as exogenous.

Another problem in estimating any of these equations is that the sample may be nonrandom due to systematic patterns of exit and survival: again if these are correlated with both $X_{i}$ and $Y_{i}$, then this may produce bias in the estimates. As discussed above, such selection effects may be especially powerful when the competitive shock is very large. If the failure rate of firms is correlated with performance and the size of the shock, which seems to be a probable situation, then this may imply $\mathrm{E}\left(\mathrm{u}_{\mathrm{it}}\right) \neq 0$ and induce a bias in the estimate of $\beta_{\mathrm{t}}$. To address this issue, we estimate a survival probability function



where $\Phi$ is the normal distribution function, $Z_{i t}$ refers to observable characteristics of firms influencing competition and productivity (discussed further below), and the $\delta$ are parameters to be estimated, including vectors of coefficients associated with $X_{i 92}$ and $Z_{i t}$. Subsidiary93 $3_{i}$ indicates whether the firm is in a subsidiary relationship in 1993 and Plants $93_{i}$ indicates the number of plants in 1993, additional variables that are included in the survival equation but not the performance equation.

There may also be other variables affecting TFP. In the Russian context, ownership is a natural candidate, insofar as the state was the dominant owner for decades while the privatization program produced a quite heterogeneous ownership and corporate governance structure by 1994 . If this heterogeneity is correlated with market structure (for instance, because more competitive sectors were more likely to be privatized), then estimates of $\gamma_{0}$ will be biased. Of course, ownership may suffer from endogeneity problems as well; because our ownership measures consist of a set of dummy variables by ownership type, in one set of specifications, we take the possible endogeneity into account using a selection bias correction.

Other factors affecting TFP, as discussed in Section 2 above, include initial conditions and the magnitude of the demand shock faced by the firm, as the state cut its orders drastically and customer and supply chains broke down (Blanchard and Kremer, 1997). A firm with better initial conditions may have been more cushioned from the impact of competition, while a greater shock suggests that firms may have greater difficulty adjusting and maintaining TFP. Our controls for initial conditions include affiliation in the Military-Industrial Complex, the share of exports in its total output in 1993, and its profitability in 1992.

We also include the change in real industry and regional output and in industry producer price indices under the assumption that these represent exogenous factors that may be correlated with unobserved shocks to a firm's productivity and possibly with competition and ownership as well. We hypothesize that firms facing a greater demand shock will have more difficulty maintaining productive efficiency, due to the costs of laying off workers, unbundling equipment and other capital, etc. A greater price change, though, should give firms more of a cushion, allowing them to delay restructuring. As discussed in Section 2, the effects of these variables may also reflect market conditions in a firm's environment: particularly for declining firms, maintaining TFP may be easier when the industry and region is growing, facilitating the release of workers and capital to other firms. We also include industry group dummies (9 groups) and the percentage of firm output reported as "consumer goods." These controls may also help to take into account problems in the measurement of the capital stock, for instance due to some firms inheriting relatively modern equipment, since such variation is likely to be correlated with initial conditions and industry affiliation.

In addition, there may be aggregate fluctuations over time; certainly such time effects would appear to be important in Russia. Finally, the factors of production may themselves be endogenous; 
we instrument them using their 1992 values. To summarize, assuming all of these considerations enter the error term in linear form, they can be summarized as

$$
u_{i t}=\alpha_{i}+\alpha_{t}+e_{i t}+\beta^{\prime} Z_{i t}+x_{i t}+f_{i t}+v_{i t},
$$

where $\alpha_{i}$ is a random firm effect, $\alpha_{t}$ are fixed time (year) effects, $e_{i t}$ is the component of the error associated with sample selection bias due to nonrandom exit and survival, $Z_{i t}$ refers to observable characteristics of firms influencing competition and productivity (such as ownership, initial conditions, the magnitude of the shock, and other conditions in the firm's market environment) and $\beta$ is the associated vector of parameters, $x_{i t}$ is the component of the error arising due to endogeneity of the elements of the competition vector $X_{i t}$ (in specifications (5) and (5')), $f_{i t}$ is the component due to endogeneity of the factors of production, and $v_{i t}$ is a mean-zero error with $E\left(X_{i t} v_{i t}\right)=0$.

\section{Data}

The firm panel data in this study are constructed from three sets of sources. The most important set consists of the Goskomstat (State Committee for Statistics) Industrial Registry: annual industrial censuses on all Russian industrial enterprises with 100 or more employees and those with fewer than 100 employees that are at least 25 percent owned by other legal entities (including the state or governmental bodies). The data do not cover industrial enterprises with fewer than 100 employees and more than 75 percent owned by individuals or industrial divisions of non-industrial enterprises (representing 9.5 percent of industrial employment in 1992). Similarly to industrial surveys and censuses in the US, only a small number of variables are collected, but they are sufficient to permit us to measure market structure quite precisely along a number of dimensions (as described below) and to estimate three-factor production functions. We have obtained files for these registries for each of the years from 1993 to 1998, but as each file contains previous year information for most of the variables, we are able to make use of the year 1992 data as well, although we do not observe enterprises that exited between 1992 and 1993.

We supplement the Goskomstat Industrial Registry database with information from two other sources. First, a Foreign Direct Investment (FDI) database, an annual registry with all foreign-owned firms and joint ventures in Russia permits us to add a substantial number of firms with foreign ownership in all years except 1996, when the Industrial Registry contains nearly all of the foreignowned firms, and 1998, when the FDI database is not yet available. Second, we added some additional enterprises and filled in missing values for enterprises already in the database from a panel database constructed by Economics, Analysis, and Marketing, Inc. (EKAM) of Moscow using a second version of the Goskomstat annual industrial censuses.

We constructed a panel by matching enterprise identification codes (OKPOs) across the supplemented registry files. Each registry contains 3,000-4,000 OKPOs not in previous registries, and a similar number of OKPOs drop out of each subsequent registry. Some of this is due to genuine firm entry and exit, some due to non-reporting enterprises, and some to enterprises that re-registered, receiving different OKPOs. For all the OKPOs not having data in every registry, we searched in all the other registries for matching enterprises by using names, addresses, industries, employment, and output values. By so doing, we were able to link 1,094 enterprises in 1993 whose OKPOs appear to have changed in a later year, 708 in 1994, 606 in 1995, 203 in 1996, and 78 in 1997. Since the registries contain previous year as well as current year values, we were able to fill in entire years of data for several thousand enterprises that existed in a particular year, but for some reason did not report.

The definition of the unit of observation is an important issue in our treatment of the data. To start with, we should emphasize that our data pertain to firms, as is most appropriate for measuring market structure, rather than establishments. The definition of the firm deserves further comment, however. In the process of linking enterprises across years, we identified several hundred cases where both consolidated data and data for subsidiaries appeared. In such cases, the name of the parent enterprise and the word "subsidiary" usually appeared somewhere in the field for the name of the subsidiary, and employment of the subsidiaries usually added exactly to the employment of the consolidated record. We avoid double-counting by excluding either consolidated entities or subsidiaries, but choose between these based on the purpose at hand: we define the unit of observation to be the consolidated entity when we measure product market concentration at the national level, but 
use the information on subsidiaries instead in measuring product market concentration withip regions and labor market concentration within cities, and when estimating our productivity equations.

The top half of Table 1 shows the construction of the sample used to compute our competition measures. The first three rows contain the number of observations obtained from the three sources, and the fourth shows the total number. The sample sizes for computation of the national and regional product market and labor market concentration measures are shown in the following three rows, respectively labeled "Total (minus subsidiaries) with non-missing output and industry;" "Total (including subsidiaries, minus all consolidated) with non-missing region, output, and industry;" and "Total (including subsidiaries, minus all consolidated) with non-missing employment and city."

The bottom part of Table 1 shows the construction of the sample for the regression analysis. As discussed above, here we include subsidiaries wherever possible and exclude redundant consolidated firms (that is, firms for which we are able to include subsidiaries); the total is shown in the first row of this part. From this total in each year, we excluded firms classified as public organizations (non-profit firms and those belonging to the ministry of culture, the environment, health, or the interior - the database contains a number of prisons). We have also excluded enterprises that have fewer than 100 employees in any year, because the database includes only firms in this category with at least 25 percent ownership by a legal entity, which skews the sample. Finally, missing data are a significant problem in the database, creating a final restriction on firms included in our sample for regression analysis. The most important restriction stems from the fact that our research question concerns the impact of the competitive shock of 1992, thus requires information for that year and indeed pertains only to firms that existed at that time. New start-up firms, likely to be intrinsically different in many respects from the enterprises inherited from the socialist system, are therefore excluded from our sample, which is in any case necessary since such firms entered only after 1992 or were very small in 1992, so would not be in the 1993 registry.

The regression sample thus restricted contains 1992 to 1998 data for an unbalanced panel of 14,961 industrial enterprises (39 firms provide 1992 information but are missing output in 1993, explaining the apparent discrepancy with the 1993 figure in the bottom row of Table 1). This sample covers 75 percent of total industrial employment in 1993, as reported by Goskomstat.

Next, we turn to a discussion of our measures of competitive pressure, shown in Table 2 (variable mnemonics are defined in the appendix). Concerning product market structure, our data permit us to calculate conventional measures, including the national Herfindahl-Hirschman Index (HHI) or any concentration ratio or dispersion index, since the database contains the population of large firms. We calculate these measures at the most disaggregated level available: the Russian 5-digit industry classification $(\mathrm{OKONKh})$, of which there are 318 separate categories in the database. As discussed in Joskow, Schmalensee, and Tsukanova (1994) and Brown and Brown (1999), the 5-digit OKONKh is roughly comparable to 4-digit categories in the U.S. Standard Industrial Classification, although some sectors are less and others somewhat more disaggregated.

Table 2 shows the national output HHI and CR2 (2-firm concentration ratio) for the years 1992 through 1998. Note that for convenience of comparison across a variety of measures, we have defined the competition measures as 1-HHI and 1-CR2, respectively. It is notable that the data so measured show a slight decrease in competition over this period, consistent with the findings of Brown and Brown (1999). The table also shows the mean number of firms by 5-digit industry and the corresponding Gini coefficient, an alternative measure of dispersion; the rise in the Gini implies more inequality in output across firms within a 5-digit industry.

As we have argued in Section 2 above, the appropriate definition of the market in Russia may be more geographically constrained than the national concentration measures indicate. Therefore, we also calculate regional concentration measures at the level of subject of the Russia Federation (oblast, of which there are 77 in the database)? The mean values by year of 1-RegHHI and 1-RegCR2 are

\footnotetext{
${ }^{6}$ We also conduct one test of the importance of Soviet-era "production associations," where all firms in the same industry are so grouped when we measure product market concentration, as described further below.

${ }^{7}$ There are 89 subjects of the Russian Federation. The database does not include data from Chechnya or Ingushetia, and the ten autonomous districts (okrugi) are aggregated together with the regions that surround them.
} 
displayed in Table 2, showing less competition within regions than nationally, and again showing a slight decline in measured competitive pressure over the years of the sample.

But the appropriate definition - whether regional, national, or some combination of the two likely varies across industries, and so we have also constructed mixture variables, which are linear combinations of the regional and national measures with firm-level weights given by variables that may be associated with the geographic scope of the market. One weighting variable is the proportion of consumer goods (final goods) in a firm's output, ConShare if consumer goods are more likely to compete within a region, while producer goods compete nationally, then the regional concentration measure is more appropriate the greater the share of consumer goods. 1-MixedHHI and 1-MixedCR2 in Table 2 are the resulting mixture variables. An alternative weight, which varies across regions, is a measure of transportation infrastructure quality; regions with better transportation infrastructure are more likely to participate in the national market than those with poorer transportation, as explained below.

Similar measures for market share defined nationally, regionally, and mixed are also shown in Table 2. Again, the data show a rise, on average, in the market share of firms in the sample.

We also consider the international dimension of competition, particularly important in an economy that had been protected for decades and where new start-ups could only very gradually begin to compete with the incumbent enterprises. Our measure of import penetration is defined conventionally as the ratio of the value of imports to the value of domestic consumption (calculated as output - exports + imports) in a five-digit sector. We computed this using the USD value of Russian imports and exports, obtained from the Russian Customs Committee on traded goods classified by the United Nations harmonized product codes (6-digit HS codes). These codes were assigned to ISIC3 (international standard industrial classification revision 3) industry codes, using a very detailed description of the ISIC3 codes, and then converted to OKONKhs, using Goskomstat's conversion from OKONKh to ISIC3. Unfortunately the conversion is not always one-to-one; when there were multiple OKONKhs, then firms are matched into ISIC3 categories according to detailed information on their products in the registry, and when there were multiple ISIC3 categories per OKONKh, then the former were distributed over the latter proportionately. Monthly exchange rates and monthly domestic output data were used to calculate the yearly weighted average exchange rate by OKONKh and convert domestic output from RUB to USD.

Combining the information on imports, exports, and domestic output (from the database) enabled us to compute import penetration ratios, Imports shown in Table 2. Imports increased sharply from 1992 to 1996, but the trade information is available only through 1996, unfortunately; in our regressions, we assume that import penetration was constant thereafter.

The final measure of competition shown in Table 2 concerns the labor market. We have coded 3,756 localities ("cities") consisting of the urban or rural district where firms in the regression sample are located. For each of these we have calculated the HHI for industrial employment as a measure of local labor market concentration. Subtracting from 1 to turn this into a measure of competition, we have the variable LaborComp in Table 2, which shows a slight decline over the 199298 period.

It is a well-documented empirical regularity that concentration ratios tend to be quite similar across countries. Pryor (1972), for instance, estimated regressions of the concentration measures for a set of industries in one country on the like measure of the same industries in the United States, finding coefficients close to one, and with high $\mathrm{R}^{2} \mathrm{~s}$. It is thus particularly striking that the correlation between product market concentration indices in Russia and the U.S. has been found to be rather small (Joskow, Schmalensee, and Tsukanova, 1994; Brown and Brown, 1999); in the latter study, the $\mathrm{R}^{2}$ is close to zero. Table 3 shows how concentration measures have evolved in Russia since the 1992 liberalization shock, using a similar method to Pryor's, but here we regress the set of indices for one year on the set for 1992. Product and labor market concentration appear to have evolved only slowly, with some tendency for a flattening of the relationship: more concentrated sectors and local labor markets have had a greater tendency than less concentrated ones to become less concentrated. With respect to Imports, however, the relationship is weak: apparently, Imports are quite volatile across sectors. While domestic market structure evolves only slowly (as shown by the high $\mathrm{R}^{2} \mathrm{~s}$ of the estimated equations, Imports may be quite responsive to changing conditions. 
Table 4 provides descriptive statistics on the variables we employ in the analysis (with mnemonics again defined in the appendix) for the sample used in the regressions. To proxy for $Y_{i}$, we use output, as value-added is unavailable, and we deflate by the 5 -digit level producer price index. $L_{1 t}$ is production worker labor and $L_{2 t}$ is non-production labor, while $K_{t}$ represents the firm's productive capital stock: plant and equipment used in production. Although capital stock measures were notoriously unreliable due to arbitrary pricing during the Soviet period, most investment from that period has already depreciated away, and recent investment has taken place at market prices, so that the figures increasingly represent standard historical cost accounting. Our data also helps to resolve a particular difficulty, which concerns the occasional year-end revaluation of the capital stock due to inflation. The data contain capital stock figures for the beginning and end of year, as well as the average over the course of the year. We use the average figure in our estimations below, but we are able to detect revaluations by comparing the end of one year figure with the beginning of year figure for the next year. In this way, we were able to build up consistent series for the capital stock for most firms in the sample.

In addition to output, the three factors of production, and the competition measures discussed above, we include two more variables in Table 4, both from year 1992. The first, 1-PAMixedHHI, redefines firms according to their membership in production associations during the Soviet period, which were more or less tightly knit groups of firms frequently in supply relationships with one another. Using the assumption here that former members of the same production association do not compete with one another, we classify firms operating in the same industry and within such an association as single entities for the purpose of computing the 1992 product market HHI. The second, Transport, is an index of the transport infrastructure in the region (subject of the Russian Federation) in which the firm is located. We have constructed this variable based on Institute for Advanced Studies (1998), but have reversed the variable (dividing by 10 and then subtracting from 1), such that the larger the number, the better the region's transport infrastructure relative to other regions. The index is based on the proximity of the region to a non-freezing port, proximity to a main transportation junction, the average distance between settlements, the number of road accidents per 100,000 population in 1996, the number of big airports in 1996, the airport capacity in 1995, the railway density in 1996, the density of railways in common use in 1996, the share of railways with electric power supply measured by length, car road density in 1996, inner water-ways density in 1996, and the number of large sea ports in 1996.

Descriptive statistics for other regressors can also be found in Table 4. Ownership is measured as a categorical variable by type, based on the measures supplied by Goskomstat. State ownership is disaggregated into FedGov, RegGov, and MuniGov categories, which is useful to test hypotheses about the degree to which different levels of government may tend to interfere in enterprise behavior in order to accomplish political objectives. The Goskomstat defines these categories as 100 percent ownership by each level of government, respectively. Firms of "MixedOwn" ownership have both state and private owners, but unfortunately there is no information on the relative importance of each. The MixedOwn group probably contains most privatized firms, as it includes 43 percent of the sample and Earle and Estrin (1997) have shown that the state retained some shareholdings in most such firms in mid-1994, while it is clear that subsequent privatization has proceeded quite slowly. But the "Private" category is also large (39.1 percent of the sample), and our sample selection rules should exclude nearly all new start-ups, so these firms are likely to have been privatized as well. Foreign is distinguished from domestic private ownership, although the former category accounts for only a tiny proportion of the sample (.8 percent). Unfortunately, there is otherwise no information on types of private owners, whether insiders or outsiders, and none whatsoever on the concentration of ownership.

Table 4 also shows our measures of firm initial conditions of potential viability affecting restructuring and the magnitude of demand shocks: Military, a dummy variable for firms in the military-industrial complex (a formal subordination to one of the Russian military ministries),

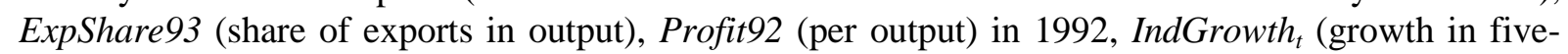
digit industry output), RegGrowth (growth in regional output), and PriceCh $_{t}$ (the log ratio of the Goskomstat price deflator for the year to the previous year prices for the five-digit industry) as a measure of relative price change. Other variables, not shown, include the percentage of consumer 
goods in total output, ConShare; and eight industry group dummies (the other industries group is the omitted category in regression analysis).

Finally, the table shows the additional variables used in our survival regression: Survival, a dummy equal to one in each year the firm remains in the database; Plants93, the number of plants in the firms in 1993; and Subsidiary93, a dummy for being in a subsidiary relationship (as either parent or daughter) in 1993. The latter two variables constitute our exclusion restrictions: they enter the survival regression, but not the productivity equation.

\section{Results}

We begin by reporting the results from estimating the survival probability regression, equation (6), then move on to the results from estimating equations (4) and (5) with the error component structure specified in equation (7), followed by a consideration of the dynamics of response to the competitive shock as in equations (4') and (5'), of alternative specifications of the competition measures, and of the results for ownership.

To take into account selection bias due to enterprise exit from the sample, we employ control function methods (Heckman, 1979). Exit may occur because of shutdown, re-organization (split-up or merger), or dropping out of the sample for other reasons; unfortunately we cannot distinguish the "true" deaths of firms from the re-organizations and non-reporting incidents. If they are non-random, even the latter may cause selection bias, however, and thus we must include them. We first run a probit regression using all industrial enterprises in 1992 with non-missing values, where the dependent variable is a dummy for whether the enterprise was still in the database in each subsequent year (reporting non-missing values for output, the two types of labor, and capital), as in equation (6) above.

In addition to the determinants of total factor productivity, we include two variables in the survival regression which are excluded from the TFP regressions. The first is a dummy representing whether the enterprise was in a parent-subsidiary relationship in 1993, Subsidiary, because such enterprises were more likely to undergo reorganizations leading to shutdowns of part of the consolidated entity. Holding companies and conglomerate enterprises were often reorganized during privatization; in some cases the divisions became independent and the holding company disappeared, while in others the holding was consolidated and the divisions stopped reporting independently. The second variable is the natural logarithm of the number of plants the firm had in 1993, Plants, included for similar reasons as Subsidiary. We have no reason to believe that either subsidiary relationships or number of plants should affect the total factor productivity of firms, however, motivating our exclusion of the variables from the TFP regressions. We use the inverse Mills' ratio from this probit (SurvMills) in all the second stage regressions in the paper.

Table 5 reports the results from estimation of equation (6), the survival regression. The 1 MixedHHI92 product market competition variable enters negatively, as does the Imports 92 variable, suggesting that the liberalization shock may have driven some firms out of business. LaborComp is estimated to have a negative effect, although it is too imprecisely estimated to be statistically significant, but Transport is estimated to have a strongly negative and significant effect, suggesting that firms in regions with good transportation infrastructure are more exposed to competitive pressure. Compared to firms owned by the Russian Federation, all other ownership types are more likely to survive except for Private and Foreign, which has the lowest survival probability. The results for the initial conditions and demand shock variables are consistent with our hypotheses: Military is estimated to negatively affect survival, while ExpShare93, size, profitability, industry and regional growth, and price change enter positively. Finally, Plants has a positive and Subsidiary has a negative impact, confirming our interpretation of the possible roles of these variables in determining the survival probability.

While the survival issue may deserve further research, for present purposes we are most interested in calculating the inverse Mills' ratio (SurvMills) for inclusion in our TFP equations, basic results for which are shown in Table 6. The first two columns contain the estimate of equation (4), the "quasi-experimental model" with market structure measured as fixed in 1992, the second differing from the first by the addition of random effects to the model. The third and fourth columns contain estimates of equation (5), where market structure varies across time, but is instrumented with its 1992

\footnotetext{
${ }^{8}$ In fact, there is little difference in the results when we ignore the potential bias.
} 
value; again, the final column adds random effects to the model. All the models appear to fit the data well, with $\mathrm{R}^{2}$ of about 0.58 , and the implied marginal products are positive and of plausible orders of magnitude for the three factors. The coefficient on SurvMills is negative, but its inclusion does not affect the qualitative findings.

The competition indicators in the specifications shown in Table 6 include our preferred "mixed" measure - 1-MixedHHI, combining 1-NatHHI and 1-RegHHI - as well as Imports, LaborComp, and Transport. All four competition variables are estimated to have positive effects on TFP in all four specifications. The magnitudes differ little when random effects are added to the model, but are larger in equation (5) estimates for product market competition measures, especially for import penetration. The increase in magnitudes for these dimensions of competition is likely due to their more rapid evolution compared with labor market competition, as was clear from the analysis in Table 3 above. The time pattern of the impact of these variables is discussed further below. The positive impact of Transport may be reflecting the cushion from competition in more remote regions, as well as the greater costs for firms in such regions to obtain inputs and sell their goods outside their region.

Concerning ownership, the specifications in Table 6 contain a disaggregation into six categories, with FedGov omitted. Overall, they suggest that private (non-state) firms - the bottom three categories - outperform state firms. Inclusion of the random effects reduces the differential of the MixedOwn, Private, and MuniGov categories, relative to FedGov. Later in this section, we discuss the ownership results in more detail and provide estimates where we account for potential selection bias through an endogenous treatment of ownership.

Concerning other independent variables, the Table 6 results concerning initial conditions are quite consistent across models, and they are largely consistent with our motivations for including them: positive initial conditions, associated with Profit92 are estimated to raise TFP, while affiliation with the Military-Industrial Complex reduces it. Somewhat surprisingly, the share of exports in total output is estimated to reduce TFP, though when we replace ExpShare93 with a simple dummy for ExpShare93>0 (not reported here), we obtain a positive coefficient that is significant at one percent. The statistically significant estimated coefficients on the demand shock indicators IndGrowth , , RegGrowth ${ }_{t}$, and PriceCh $h_{t}$ are consistent with both conjectures we have offered: On the one hand, these variables may be reflecting idiosyncratic shocks to the firm, suggesting downsizing firms may have greater difficulties in maintaining productivity. On the other hand, they may also be reflecting factor supply effects in the market environment, making it easier for contracting firms to release factors and maintain productivity. Price $h_{t}$ is estimated to reduce TFP, consistent with a budgetsoftening effect for firms in industries with positive price shocks. The magnitudes of the estimated coefficients fall when individual firm random effects are added to the models, but only RegGrowth becomes statistically insignificant at conventional levels. Controlling for the other variables, TFP shows a declining trend over the sample period.

We present the results from estimating equations (4) and (5) with alternative specifications of the competition measures and alternative estimation techniques below, but first we turn to estimation of equations (4') and (5'), where we permit the effect of the competition measures to vary across years. The results, which appear in Table 7, show that the time-invariant estimates of the base specifications mask some trends in the impact of competition. With respect to our preferred measure of competitive pressure in the product market, 1-MixedHHI, the impact in specification (4') is estimated to be negative in 1993 and 1994, although not statistically significant, and the magnitude of the coefficient grows steadily, reaching what appears to be a long-run impact of about 25 percent only after four years. The results for 1-MixedHHI in specification (5') is similarly trended, although the coefficients are larger in every year, consistent with the difference in Table 6 . The estimated impacts of the other three competition measures do not reflect strong trends, in the case of Imports and LaborComp because the coefficients are quite stable across years, while the coefficient on Transport is quite volatile, if consistently positive and nearly always statistically significant. The results support the hypothesis that there may be some lag in the responsiveness of firms to a competitive shock in the domestic product market, but there is little evidence of such a lag with respect to the other dimensions of competition.

Next, we turn to the question whether the effects of competition are non-linear. Table 8 shows simple quadratic specifications of the competition variables, where the rest of the specification is the 
same as in Table 6, Columns 1 and 3 (Equations (4) and (5) without random effects). Domestic product market competition appears to have a convex effect on TFP, with an implied negative slope at low levels in specification (4), but still strongly positive in the relevant range (the mean 1-MixedHHI from Table 4 is .81). The impact of import penetration is estimated to be strongly concave, however, in specification (4) actually turning negative after a penetration rate of about 35 percent. This is consistent with the view that "too much" or "too tough" competition may actually discourage firms from attempting to improve their performance. With respect to labor market competition, the results again imply a convex relationship, one that is also positive over the relevant range. The convexity suggests that this variable matters most in differentiating very dynamic and competitive labor markets from the majority of stagnant, uncompetitive ones in Russia. With respect to Transport, the results imply an initial decline followed by a rise in the estimated effect, with a positive effect from a level of about 0.4 onwards. Somewhat paradoxically, the marginal impact of Transport is estimated to be negative at its mean value (.3) in Russia.

We investigate the effects of alternative measures of market structure on total factor productivity growth, since some previous studies have found different results from different measures and theory does not clearly point to one measure being superior to another. Robustness is therefore an important issue. Panel A of Table 9 shows the results from running the regressions in the first and third columns of Table 6 with alternative measures of market structure. With the exception of 1 NatHHI and 1-PAMixedHHI, where we use production associations rather than firms in defining the competition measure, all specifications of competitive pressure provide strong evidence that domestic competition has a disciplining effect on enterprises. The statistically insignificant findings with respect to these exceptions probably reflect the inappropriateness of assuming that competition takes place only at the national level in Russia and that production associations represent significant collusion for the exercise of market power, respectively. The negative coefficient on 1-PAMixedHHI suggests that the former members of these associations, which include firms in the same industry, are actually competing with one another, contrary to popular claims in Russia. When we include both 1 NatHHI and 1-RegHHI in a single specification, the results strongly suggest that l-RegHHI is the better measure of competitive pressure, further buttressing our contention of the importance of geography in understanding Russian industrial organization. A similar finding does not appear for market share, however, where all three measures - national, regional, and mixed - produce positive and statistically significant results (even when both national and regional are both included as regressors in the same specification).

We also investigate robustness with respect to estimation technique and specification of the production function. Panel B of Table 9 shows the results when we use the least-absolute-deviations method, which estimates the conditional median rather than the conditional mean as a function of the regressors and is therefore robust with respect to outliers, while Panel $\mathrm{C}$ shows the results when we interact all the factors of production (including higher-order terms) with nine industry dummies to permit heterogeneity in the production function. The results demonstrate that not only the qualitative conclusions, but also even very similar magnitudes of estimation results, are robust to these changes in our methodology.

Our results on the geographic dimension of competition motivate us to consider the role of transportation infrastructure more closely. Table 10 shows the estimation results where we interact Transport with the other dimensions of competition and where we use Transport as the mixing variable (in place of ConShare) in constructing a mixed national-regional competition measure. In the top specification, for both Equations (4) and (5), Transport is estimated to enhance domestic product market competition (1-MixedHHI), suggesting that competitive pressure by this measure is more effective when the frictions of transportation costs are reduced. The interaction with import competition shows inconsistent results across the two specifications, however: in Equation (4), import competition is enhanced by Transport, while in Equation (5), it is diminished. Increases in Transport are estimated to reduce the impact of labor market competition, suggesting that high municipal labor market concentration may not give firms as much monopsony power when transportation infrastructure is better, as workers will be able to commute to jobs in other cities more easily. Controlling for these interactions, the main Transport effect is estimated to be positive in both

\footnotetext{
${ }^{9}$ See Kwoka (1981).
} 
specifications, although the magnitude and statistical significance is much greater in Equation (5). The bottom two specifications, which employ Transport as the mixing variable, show results fairly similar to those we obtained when ConShare was used to mix the national and regional competition measures. This demonstrates, from another viewpoint, that it appears to be inappropriate to define product markets as either national or regional; rather, the geographic scope varies across industries and is some combination of the two.

Finally, we provide a more detailed analysis of the effects of ownership in Table 11. Recall the result in Table 6 that non-state firms are estimated to outperform state-owned ones; in the first "OLS" specification in Table 10, we reproduce those results, including in the first column an aggregation of the three types of non-state ownership: mixed, 100 percent private, and foreign-owned companies. To control for the possibility of bias in the privatization process (the allocation of firms to various ownership categories), for instance that the enterprises with the best (or worst) prospects for total factor productivity growth were privatized, we again use the Heckman selection procedure. We first run a probit regression with the non-state dummy as the dependent variable, using the share of non-state enterprises in the region and in the branch ministry as additional variables in the probit, because the privatization process was highly influenced by regional authorities and branch industry officials (Boycko, Shleifer, and Vishny, 1995). ${ }^{10}$ Enterprises in strategic branches (such as the MIC) required special permission to be privatized or were banned from privatization altogether. We then insert the inverse Mills' ratio from the probit regression (lambda) in the second-stage performance regression along with the ownership dummy. We estimate the second stage equations with and without random effects.

The results of the first-stage probit (not shown) suggest that non-state enterprises tend to have significantly higher employment, face more product market, labor market, and import competition, exported less in 1993, have initially higher profitability, are less likely to have been in the MIC, and are located in areas with poorer transportation infrastructure. Table 11 shows the second-stage regression results, including the Mills' ratio from the first stage in the second and fourth specifications. Non-state ownership is estimated to have a positive effect in all specifications, although the magnitude of the coefficient is substantially lower in all specifications compared to the OLS. It is statistically significant at the 1 percent level except in the $2^{\text {nd }}$ specification, where it meets only a 10 percent criterion.

To handle possible selection bias in the multiple-ownership category case, we run a multinomial logit for the selection procedure, and then include the inverse Mills' ratios for each ownership category in the second stage regressions, which are shown in Table 11. The results are similar to the uncorrected OLS, except that the coefficient for RegGov becomes statistically significant and the coefficient for MuniGov doubles.

The final two sets of results in Table 11 add random effects, with and without selection correction. These show less consistency across specifications than did the Non-State dummy coefficient. Foreign has a consistently large coefficient, as does Private except in the final specification, although even there it is statistically significant. MuniGov is large and positive except in the random effects specification without selection correction, where the coefficient becomes statistically insignificant. Perhaps the most sensitive variable is MixedOwn, whose coefficient steadily falls across the four specification, essentially reaching zero when both random effects and the selection bias correction techniques are applied. Clearly, these results for ownership must be treated cautiously, as the measure available to us in these data is rather crude.

\section{Conclusion}

Weaned on models of competitive equilibrium, economists instinctively tend to invoke the virtues of competition in a wide variety of situations. But this usually unreflective appeal to competitive forces has received remarkably little empirical testing and verification, and even when it has been tested, the evidence has been rather weak. We speculate that the paucity of empirical support

\footnotetext{
${ }^{10}$ We use the entire database to calculate ownership shares by branch ministry and by region $(17,099$ enterprises used for the branch ministry shares and 23,044 used for the regional shares). There are 136 branch ministries and 77 regions (oblasts) in the panel.
} 
is a result of the difficulty of observing these forces at work in equilibrium, or at least in the rather stable conditions of most economies in which such studies have been conducted.

In this paper, we have exploited the quasi-experiment offered by the Russian economy in transition to avoid the endogeneity problems that plague other analyses and to observe the potentially large efficiency effects that may be present in enterprises inherited from the socialist period. Our analysis embraces a variety of dimensions of competitive pressure, including not only domestic market structure at the national level, but also import competition, regional variation of product markets, transportation infrastructure, and labor market competition. We have studied the time path of the impact of a competitive shock - the abrupt liberalization of prices, entry, imports, and labor mobility in January 1992, and examined non-linearities in the effect of each of these competitive forces. Our data set permits us to investigate virtually any measure of product market competition that has been proposed, and our results are strongly robust across alternative specifications.

The results provide strong evidence that domestic product market competition, import competition, and local labor market competition have strong positive effects on total factor productivity. The impact of liberalization appears only gradually in the domestic product market, taking about four years to attain about 90 percent of the long-run value, but we find no such lags with respect to import competition or labor market competition. Better transport infrastructure appears to turn potential product market competition into actual competition, while at the same time reducing firms' monopsony power on the labor market by facilitating worker mobility across municipalities. We also find that non-state firms outperform state enterprises, even after controlling for selection bias in the determination of ownership. 


\section{Appendix 1. Definitions of Variables}

ConShare is the share of consumer goods (final goods) in the enterprise's total output in 1993.

Emp92 is the log of the enterprise's 1992 industrial employment.

ExpShare93 is the enterprise's share of exports in total production in 1993.

FedGov is a dummy equal to 1 if the firm is owned by the federal government.

Foreign is a dummy equal to 1 if the firm is foreign owned or is a foreign-domestic joint venture .

1-Gini is one minus the Gini coefficient for the five-digit industry using output shares at the national level. A larger number signifies greater equality of output shares.

Imports is the import penetration ratio: the share of imports in domestic sales in the five-digit industry.

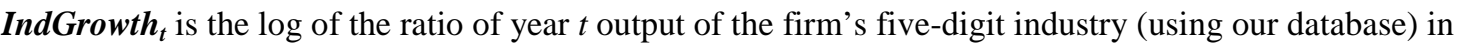
December 1992 prices to the previous year output of the industry in December 1992 prices.

$\boldsymbol{K}_{t}$ is the book value in 1992 prices of the enterprise's fixed assets used in industrial production. Revaluations are controlled for using beginning- and end-year book values.

$\boldsymbol{L}_{\boldsymbol{l}}$ is the $\log$ of the enterprise's number of production workers.

$\boldsymbol{L}_{2 t}$ is the $\log$ of the enterprise's number of non-production employees.

LaborComp is one minus the Herfindahl-Hirschman Index of the concentration of employment shares of industrial firms in the enterprise's municipality (using our database). There are 3,756 municipalities in the panel.

Military is a dummy equal to 1 if the enterprise formerly belonged to an MIC branch ministry.

MixedOwn is a dummy equal to 1 if the firm is partially owned by the state and partially by non-state entities.

1-MixedCR2 is $(1-R e g C R 2) *$ ConShare $+(1-N a t C R 2) *(1-C o n S h a r e)$.

1-MixedHHI is (1-RegHHI)*ConShare + (1-NatHHI $)^{*}(1-C o n S h a r e)$.

1-MixedMktSh is (1-RegMktSh)*ConShare + 1-NatMktSh*(1-ConShare).

MuniGov is a dummy equal to 1 if the firm is owned by the municipal government.

1-NatCR2 is one minus the national output share of the two largest enterprises ranked by output in the five-digit Russian industry (OKONKh), of which there are 318 in our panel.

1-NatHHI is one minus the Herfindahl-Hirschman Index (sum of squared output shares of each firm in the industry) for the five-digit industry at the national level.

1-NatMktSh is the employment share of the enterprise in its five-digit industry at the national level.

Nat No. Firms is the log of the number of firms in the five-digit industry at the national level in 1992.

Non-State is equal to Private + Foreign + MixedOwn

PA1-MixedHHI is 1-MixedHHI, except where the regional and national HHI are modified to treat production associations as if they were single firms. The output of all firms in production association $\mathrm{X}$ and in industry $\mathrm{Y}$ was summed prior to calculating the national $\mathrm{HHI}$, and the output of all firms in production association X, industry $\mathrm{Y}$, and region $\mathrm{Z}$ was summed prior to calculating the regional $\mathrm{HHI}$.

Plants93 is the log of the number of plants in 1993. 
PriceCh $\boldsymbol{h}_{t}$ is the log of the year $t$ average producer price deflator relative to December 1992 for each five-digit industry. The average producer price deflator was constructed using Goskomstat monthly deflators and volume of production statistics.

Private is a dummy equal to 1 if the firm is $100 \%$ owned by private entities.

Profit92 is the enterprise's profits (losses) divided by output in 1992.

RegGov is a dummy equal to 1 if the firm is owned by the regional government.

1-RegCR2 is one minus the regional output share of the two largest enterprises by output in the five-digit industry in the region in which the enterprise is located. There are 77 regions in the panel.

RegGrowth ${ }_{t}$ is the log of the ratio 199X industrial output of the region in 1990 prices divided by the previous year output of the region in 1990 prices. The output numbers were calculated by Goskomstat (not from our database).

1-RegHHI is the Herfindahl-Hirschman Index (sum of squared output shares of each firm in the industry) for the five-digit industry at the regional level.

1-RegMktSh is the employment share of the enterprise in its five-digit industry at the regional level.

Subsidiary93 is a dummy equal to 1 if the enterprise was either a subsidiary or parent to a subsidiary in 1993.

SurvMills is the inverse Mills' ratio from the first-stage probit for whether the enterprise survived or not.

Transport is an index of the region's transport infrastructure from 0 to 1 , such that the larger the number, the better the region's transport infrastructure relative to other regions. constructed by the Institute for Advanced Studies (1998). We have reversed the variable (subtracting from 1), such that the larger the number, the better the region's transport infrastructure relative to other regions. The index is based on the proximity of the region to a non-freezing port, proximity to a main transportation junction, the average distance between settlements, the number of road accidents per 100,000 population in 1996, the number of big airports in 1996, the airport capacity in 1995, the railway density in 1996, the density of railways in common use in 1996, the share of railways with electric power supply measured by length, car road density in 1996, inner water-ways density in 1996, and the number of large sea ports in 1996.

1-TransportMixedCR2 is $(1-R e g C R 2) *(1-T r a n s p o r t)+(1-N a t C R 2) *$ Transport.

1-TransportMixedHHI is $(1-R e g H H I) *(1-T r a n s p o r t)+(1-N a t H H I) *$ Transport.

$\boldsymbol{Y}_{\boldsymbol{t}}$ is the $\log$ of the value of output the enterprise produced in December 1992 prices. 


\section{References}

Anderson, James H.; Lee, Young and Murrell, Peter. "Do Competition and Ownership Affect Enterprise Efficiency in the Absence of Market Institutions? Evidence after Privatization in Mongolia." Economic Inquiry, forthcoming 2000.

Aw, Bee Yan; Chen, Xiaomin and Roberts, Mark J. "Firm-level Evidence on Productivity Differentials, Turnover, and Exports in Taiwanese Manufacturing." Fondazione Eni Enrico Mattei Note di Lavoro, September 1997, 69.

Bain, Joe S. Barriers to New Competition. Cambridge: Harvard University Press, 1956.

Berger, Allen N. and Hannan, Timothy H. "The Efficiency Cost of Market Power in the Banking Industry: A Test of the "Quiet Life" and Related Hypotheses." Review of Economics and Statistics, August 1998, 80(3), pp. 454-65.

Bhagat, Sanjai and Black, Bernard. “Do Independent Directors Matter?” Working paper, 1997.

Blanchard, Olivier and Kremer, Michael. "Disorganization." Quarterly Journal of Economics, November 1997, 112(4), pp. 1091-1126.

Blanchflower, David and Machin, Stephen. "Product Market Competition Wages and Productivity: International Evidence from Establishment-Level Data." Annales D'Économie et de Statistique, January-June 1996, O(41-42), pp. 219-53.

Blasi, Joseph R.; Kroumova, Maya and Kruse, Douglas. Kremlin Capitalism: Privatizing the Russian Economy. Ithaca and London: Cornell University Press, 1997.

Boal, William M. and Ransom, Michael R. "Monopsony in the Labor Market." Journal of Economic Literature, March 1997, 35(1), pp. 86-112.

Boardman, Anthony E. and Vining, Aidan R. "Ownership and Performance in Competitive Environment: A Comparison of the Performance of Private, Mixed, and State-Owned Enterprises." Journal of Law and Economics, 1989, 32(1), pp. 1-33.

Bonin, John; Jones, Derek and Putterman, Louis. "Theoretical and Empirical Studies of Producer Cooperatives: Will Ever the Twain Meet?" Journal of Economic Literature, September 1993, 31(3), pp. 1290-1320.

Boycko, Maxim; Shleifer, Andrei and Vishny, Robert W. Privatizing Russia. Cambridge: MIT Press, 1995.

Brown, Annette N. and Brown, J. David. "The Transition of Market Structure in Russia: Economic Lessons and Implications for Competition.” Working paper, SITE, January 1999.

Brown, Annette N.; Ickes, Barry W. and Ryterman, Randi. "The Myth of Monopoly: A New View of Industrial Structure in Russia.” World Bank Policy Research Working Paper No. 1331, 1994.

Carlsson, Bo. "The Measurement of Efficiency in Production: An Application to Swedish Manufacturing Industries." Swedish Journal of Economics, December 1972, 74(4), pp. 468-85.

Caves, Richard E. and Barton, David R. Efficiency in U.S. Manufacturing Industries. Cambridge: MIT Press, 1990. 
deGhellinck, Elisabeth; Geroski, Paul A. and Jacquemin, Alexis. "Inter-Industry Variations in the Effect of Trade on Industry Performance.” Journal of Industrial Economics, September 1988, 37(1), pp. 1-19.

Demsetz, Harold. "Industry Structure, Market Rivalry, and Public Policy." Journal of Law and Economics, 1973, 16(1), pp. 1-9.

Demsetz, Harold and Lehn, Kenneth. "The Structure of Corporate Ownership: Causes and Consequences." Journal of Political Economy, 1985, 93(6), pp. 1155-1177.

Dunne, Timothy; Roberts, Mark J. and Samuelson, Larry. "The Growth and Failure of U.S. Manufacturing Plants." Quarterly Journal of Economics, November 1989, 104(4), pp. 671-98.

Earle, John S. and Estrin, Saul. "Privatization Versus Competition: Changing Enterprise Behavior in Russia." Working paper, December 1995.

"After Voucher Privatization: The Structure of Corporate Ownership in Russian Industry.” CEPR Discussion Paper No. 1736, 1997.

"Privatization, Competition, and Budget Constraints: Disciplining Enterprises in Russia." SITE Working Paper No. 128, March 1998.

Earle, John S. and Komarov, Ivan. "Measuring Defense Conversion in Russian Industry." Defense and Peace Economics, forthcoming, 2000.

Esposito, Louis and Esposito, Frances F. "Foreign Competition and Domestic Industry Profitability." Review of Economics and Statistics, 1971, 53(4), pp. 343-353.

Fischer, Stanley; Sahay, Ratna and Végh, Carlos A. "Stabilization and Growth in Transition Economies: The Early Experience.” Journal of Economic Perspectives, Spring 1996, 10(2), pp. 45-66.

Gaddy, Clifford and Ickes, Barry W. Russia's Virtual Economy. Washington D.C.: Brookings Institution, 1999.

Geroski, Paul A. "Interpreting a Correlation between Market Structure and Performance." Journal of Industrial Economics, March 1982, 30(3), pp. 319-26.

Geroski, Paul A. and Jacquemin, Alexis. "Imports as Competitive Discipline." in Symposium on Industrial Organization and International Trade, Recherches Economiques de Louvain, 1981, 47(3-4), pp. 197-208.

Goskomstat Rossii. Promyshlennost' Rossii. Moscow: Goskomstat, 1996.

Heckman, James. "Sample Selection Bias as a Specification Error.” Econometrica, January 1979, 47(1), pp. 153-161.

Hicks, Sir John. "Annual Survey of Economic Theory: The Theory of Monopoly." Econometrica, 1935.

Holderness, Clifford G. and Sheehan, Dennis P. "The Role of Majority Shareholders in Publicly Held Corporations." Journal of Financial Economics, 1988, 20(1/2), pp. 317-346.

Ickes, Barry; Ryterman, Randi and Tenev, Stoyan. "On Your Marx, Get Set, Go: The Role of Competition in Enterprise Adjustment." The World Bank, 1995. 
Institute for Advanced Studies. Russia: Regional Risk Rating. Vienna: Bank of Austria, 1998.

Jones, Derek; Klinedinst, Mark and Rock, Charles. "Productive Efficiency during Transition: Evidence from Bulgarian Panel Data." Journal of Comparative Economics, September 1998, 26(3), pp. 446-64.

Konings, Jozef. "Competition and Firm Performance in Transition Economies: Evidence from Firm Level Surveys in Slovenia, Hungary, and Romania.” CEPR Discussion Paper No. 1770, 1997.

Kornai, Janos. The Socialist System: The Political Economy of Communism. Princeton: Princeton University Press 1992.

Kwoka, John E. "Does the Choice of Concentration Measure Really Matter?" Journal of Industrial Economics, June 1981, 29(4), pp. 445-453.

Leibenstein, Harvey. "Allocative Efficiency vs. 'X-efficiency." American Economic Review, June 1966, 56(3), pp. 392-412.

Li, Wei. "The Impact of Economic Reform on the Performance of Chinese State Enterprises, 198089." Journal of Political Economy, October 1997, 105(5), pp. 1080-1106.

McConnell, John J. and Servaes, Henri. "Additional Evidence on Equity Ownership and Corporate Value.” Journal of Financial Economics, 1990, 27(2), pp. 595-612.

Megginson, William L.; Nash, Robert C. and van Randenborgh, Matthias. "The Financial and Operating Performance of Newly Privatized Firms: An International Empirical Analysis." Journal of Finance, June 1994, 49(2), pp. 403-452.

Meyer, Bruce. "Natural and Quasi-Experiments in Economics." Journal of Business and Economic Statistics, 13(2), April 1995, pp. 151-161.

Morck, Randall; Shleifer, Andrei. and Vishny, Robert W. "Management Ownership and Market Valuation: An Empirical Analysis." Journal of Financial Economics, January/March 1988, 20(1/2), pp. 293-315.

Nelson, Richard R. and Winter, Sidney G. An Evolutionary Theory of Economic Change. Cambridge: Harvard University Press, 1982.

Nickell, Stephen. "Competition and Corporate Performance." Journal of Political Economy, August 1996, 104(4), pp. 724-46.

Peltzman, Sam. "The Gains and Losses from Industrial Concentration." Journal of Law and Economics, 20(2), October 1977, pp. 229-63.

Pittman, Russell W. and Werden, Gregory J. "The Divergence of SIC Industries from Antitrust Markets: Evidence from Justice Department Merger Cases.” Economics Letters, 1990, 33(3), pp. 283-86.

Prowse, Stephen D. "The Structure of Corporate Ownership in Japan." Journal of Finance, July 1992, 47(3), pp. 1121-1140.

Pryor, Frederic L. "An International Comparison of Concentration Ratios." Review of Economics and Statistics, May 1972, 54(2), pp. 130-40. 
Repkine, Alexander and Walsh, Patrick P. "Evidence of European Trade and Investment UShaping Industrial Output in Bulgaria, Hungary, Poland, and Romania." Journal of Comparative Economics, December 1999, 27(4), pp. 730-52.

Sabel, Charles F. and Prokop, Jane E. "Stabilization through Reorganization? Some Preliminary Implications of Russia's Entry into World Markets in the Age of Discursive Quality Standards." in Roman Frydman, Cheryl W. Gray and Andrzej Rapaczynski, eds., Corporate governance in Central Europe and Russia. Volume 2. Insiders and the state. Budapest: Central European University Press; distributed by Oxford University Press New York, 1996, pp. 151-91.

Saunders, Ronald. "The Determinants of Productivity in Canadian Manufacturing Industries." The Journal of Industrial Economics, December 1980, 29(2), pp. 167-184.

Scherer, Frederic M.; Beckenstein, Alan R.; Kaufer, Erich and Murphy, R. Dennis. The Economics of Multi-Plant Operation: An International Comparisons Study. Cambridge: Harvard University Press, 1975.

Schumpeter, Joseph. Capitalism, Socialism, and Democracy. $3^{\text {rd }}$ ed. New York: Harper and Row, 1950.

Smith, Abbie J. "Corporate Ownership Structure and Performance: The Case of Management Buyouts." Journal of Financial Economics, September 1990, 27 (1), pp. 143-164.

Vining, Aidan R. and Boardman, Anthony E. "Ownership Versus Competition: Efficiency in Public Enterprise.” Public Choice, March 1992, 73(2), pp. 205-239.

Weiss, Leonard W. "The Geographic Size of Markets in Manufacturing." Review of Economics and Statistics, August 1972, 54(3), pp. 245-57.

Wruck, Karen H. "Equity Ownership Concentration and Firm Value: Evidence from Private Equity Financings." Journal of Financial Economics, June 1989, 23(1), pp. 3-28. 
Table 1. Construction of the Sample

\begin{tabular}{|c|c|c|c|c|c|c|c|}
\hline & Number of firms: & 1993 & 1994 & 1995 & 1996 & 1997 & 1998 \\
\hline \multirow{4}{*}{  } & In the Industrial Registry (minus subsidiaries) & 25,541 & 26,862 & 28,484 & 29,674 & 29,175 & 26,532 \\
\hline & Added from FDI Database & 2,448 & 3,342 & 3,638 & 28 & 2,122 & 0 \\
\hline & Added from EKAM Database & 1,144 & 2,437 & 37 & 281 & 256 & 0 \\
\hline & Total (minus subsidiaries) & 29,133 & 32,641 & 32,159 & 29,983 & 31,553 & 26,532 \\
\hline \multirow{3}{*}{ 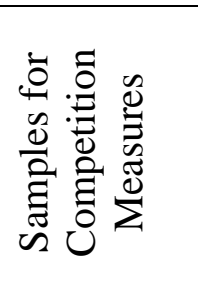 } & $\begin{array}{l}\text { Total (minus subsidiaries) with non-missing industry and output } \\
\text { (used in national conc.) }\end{array}$ & 25,546 & 27,212 & 29,926 & 28,082 & 26,522 & 24,951 \\
\hline & $\begin{array}{l}\text { Total (incl. subsidiaries, minus all consolidated) with non-missing } \\
\text { region, industry, and output (used in regional conc.) }\end{array}$ & 26,080 & 27,519 & 29,964 & 28,067 & 26,522 & 24,951 \\
\hline & $\begin{array}{l}\text { Total (incl. subsidiaries, minus all consolidated) with non-missing } \\
\text { employment and city (used in labor concentration) }\end{array}$ & 27,100 & 28,662 & 29,851 & 26,106 & 25,430 & 21,350 \\
\hline \multirow{4}{*}{ 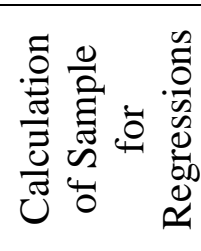 } & Total incl. subsidiaries, minus redundant consolidated & 30,074 & 33,156 & 32,315 & 30,007 & 31,553 & 26,532 \\
\hline & Minus firms classified as "Public Organizations" & 29,642 & 32,596 & 31,661 & 29,343 & 30,806 & 25,675 \\
\hline & Minus firms with fewer than 100 employees & 19,852 & 19,993 & 17,643 & 15,917 & 14,910 & 13,507 \\
\hline & Minus firms with missing values (sample for regression analysis) & 14,922 & 14,120 & 13,594 & 12,816 & 12,117 & 10,543 \\
\hline
\end{tabular}


Table 2. Means of Competition Variables

\begin{tabular}{|l|r|r|r|r|r|r|r|}
\hline Variables & 1992 & 1993 & 1994 & 1995 & 1996 & 1997 & 1998 \\
\hline 1-MixedHHI & 0.822 & 0.822 & 0.814 & 0.813 & 0.802 & 0.793 & 0.783 \\
& $(0.230)$ & $(0.230)$ & $(0.232)$ & $(0.233)$ & $(0.240)$ & $(0.245)$ & $(0.253)$ \\
\hline 1-MixedCR2 & 0.635 & 0.632 & 0.619 & 0.615 & 0.600 & 0.588 & 0.575 \\
& $(0.281)$ & $(0.281)$ & $(0.282)$ & $(0.280)$ & $(0.282)$ & $(0.287)$ & $(0.291)$ \\
\hline 1-TransportMixedHHI & 0.726 & 0.728 & 0.725 & 0.723 & 0.710 & 0.700 & 0.692 \\
& $(0.249)$ & $(0.247)$ & $(0.246)$ & $(0.244)$ & $(0.247)$ & $(0.249)$ & $(0.252)$ \\
\hline 1-TransportMixedCR2 & 0.532 & 0.530 & 0.522 & 0.519 & 0.503 & 0.491 & 0.482 \\
& $(0.255)$ & $(0.253)$ & $(0.246)$ & $(0.245)$ & $(0.244)$ & $(0.244)$ & $(0.243)$ \\
\hline 1-NatHHI & 0.956 & 0.952 & 0.950 & 0.952 & 0.944 & 0.937 & 0.944 \\
& $(0.078)$ & $(0.091)$ & $(0.096)$ & $(0.082)$ & $(0.097)$ & $(0.103)$ & $(0.090)$ \\
\hline 1-NatCR2 & 0.843 & 0.833 & 0.831 & 0.824 & 0.805 & 0.789 & 0.798 \\
& $(0.163)$ & $(0.168)$ & $(0.174)$ & $(0.163)$ & $(0.176)$ & $(0.188)$ & $(0.174)$ \\
\hline 1-RegHHI & 0.603 & 0.609 & 0.601 & 0.597 & 0.578 & 0.563 & 0.560 \\
& $(0.329)$ & $(0.325)$ & $(0.321)$ & $(0.317)$ & $(0.322)$ & $(0.325)$ & $(0.322)$ \\
\hline 1-RegCR2 & 0.353 & 0.356 & 0.341 & 0.334 & 0.317 & 0.303 & 0.299 \\
& $(0.295)$ & $(0.293)$ & $(0.282)$ & $(0.276)$ & $(0.273)$ & $(0.270)$ & $(0.266)$ \\
\hline 1-Gini & 0.396 & 0.379 & 0.358 & 0.333 & 0.319 & 0.317 & 0.308 \\
& $(0.111)$ & $(0.106)$ & $(0.104)$ & $(0.104)$ & $(0.106)$ & $(0.112)$ & $(0.106)$ \\
\hline Nat No. Firms & 648 & 664 & 621 & 639 & 621 & 578 & 544 \\
& $(691)$ & $(713)$ & $(636)$ & $(641)$ & $(638)$ & $(600)$ & $(537)$ \\
\hline 1-MixedMktSh & 0.889 & 0.893 & 0.890 & 0.886 & 0.878 & 0.876 & 0.871 \\
& $(0.215)$ & $(0.210)$ & $(0.211)$ & $(0.214)$ & $(0.222)$ & $(0.223)$ & $(0.230)$ \\
\hline 1-NatMktSh & 0.986 & 0.987 & 0.988 & 0.989 & 0.988 & 0.986 & 0.987 \\
& $(0.052)$ & $(0.051)$ & $(0.048)$ & $(0.045)$ & $(0.045)$ & $(0.053)$ & $(0.047)$ \\
\hline 1-RegMktSh & 0.727 & 0.739 & 0.743 & 0.746 & 0.736 & 0.725 & 0.723 \\
& $(0.346)$ & $(0.341)$ & $(0.338)$ & $(0.339)$ & $(0.347)$ & $(0.352)$ & $(0.349)$ \\
\hline Imports & 0.075 & 0.122 & 0.089 & 0.239 & 0.292 & & \\
\hline LaborComp & $(0.172)$ & $(0.170)$ & $(0.143)$ & $(0.232)$ & $(0.730)$ & & \\
\hline Sal & 0.260 & 0.262 & 0.265 & 0.267 & 0.253 & 0.257 & 0.249 \\
& $(0.315)$ & $(0.317)$ & $(0.320)$ & $(0.321)$ & $(0.314)$ & $(0.315)$ & $(0.313)$ \\
\hline
\end{tabular}

Standard errors are in parentheses. 
Table 3. Change in Market Structure

\begin{tabular}{|c|c|c|c|c|c|}
\hline & 1-NatHHI & I-NatCR2 & 1-NatMktSh & Imports & LaborComp \\
\hline 1993 & $0.932(36.85)$ & $0.908(39.48)$ & $0.911(49.07)$ & $0.170(3.04)$ & $0.981(330.35)$ \\
\hline & 0.876 & 0.872 & 0.940 & 0.018 & 0.933 \\
\hline 1994 & $0.786(15.94)$ & $0.837(24.27)$ & $0.796(25.81)$ & $0.086(1.52)$ & $0.938(195.60)$ \\
\hline & 0.722 & 0.725 & 0.761 & 0.006 & 0.837 \\
\hline 1995 & $0.736(13.72)$ & $0.822(23.87)$ & $0.717(18.53)$ & $0.248(3.64)$ & $0.908(155.14)$ \\
\hline & 0.696 & 0.726 & 0.640 & 0.024 & 0.779 \\
\hline 1996 & $0.746(13.71)$ & $0.809(23.10)$ & $0.717(17.88)$ & $-0.543(-1.99)$ & $0.841(115.63)$ \\
\hline & 0.588 & 0.678 & 0.625 & 0.002 & 0.710 \\
\hline 1997 & $0.782(14.28)$ & $0.840(26.48)$ & $0.646(15.05)$ & & $0.820(105.95)$ \\
\hline & 0.624 & 0.715 & 0.483 & & 0.675 \\
\hline 1998 & $0.731(14.06)$ & $0.783(18.92)$ & $0.650(15.70)$ & & 0.785 \\
\hline & 0.529 & 0.602 & 0.431 & & $0.633 .65)$ \\
\hline
\end{tabular}

These are coefficients from regressions where the dependent variable is the later year competition measure and the independent variable is the 1992 value of the competition measure. The t-statistics are in parentheses and the R-squared statistics are in the line below. 
Table 4. Means of Variables

\begin{tabular}{|c|c|c|c|}
\hline & Variable & Mean & $\begin{array}{c}\text { Standard } \\
\text { Deviation }\end{array}$ \\
\hline & $Y_{t}(\mathrm{mln} 1992$ rubles $)$ & 897 & 906,400 \\
\hline & Transport & 0.392 & 0.212 \\
\hline \multirow{3}{*}{ 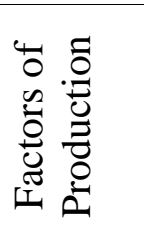 } & $K_{t}(\mathrm{mln} 1992$ rubles $)$ & 2,254 & 114,000 \\
\hline & $L_{1 t}$ & 621 & 1,944 \\
\hline & $L_{2 t}$ & 171 & 540 \\
\hline \multirow{6}{*}{ 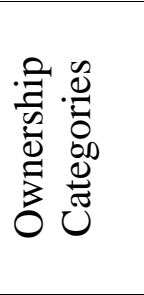 } & MuniGov $_{t}$ & 0.015 & \\
\hline & $\operatorname{RegGov}_{t}$ & 0.057 & \\
\hline & FedGov ${ }_{t}$ & 0.099 & \\
\hline & MixedOwnt & 0.430 & \\
\hline & Private $_{t}$ & 0.391 & \\
\hline & Foreign $_{t}$ & 0.008 & \\
\hline \multirow{3}{*}{ 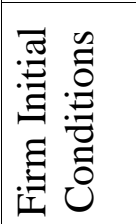 } & Military & 0.032 & \\
\hline & ExpShare93 & 0.023 & 0.081 \\
\hline & Profit92 & 0.223 & 0.163 \\
\hline \multirow{3}{*}{ 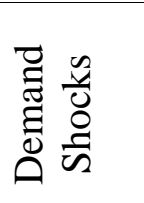 } & IndGrowth $_{t}$ & -0.219 & 0.316 \\
\hline & RegGrowth & -0.114 & 0.128 \\
\hline & PriceCh & 0.460 & 0.573 \\
\hline \multirow{3}{*}{  } & Survival $_{t}$ & 0.870 & \\
\hline & Plants93 & 1.271 & 2.894 \\
\hline & Subsidiary93 & 0.021 & \\
\hline
\end{tabular}

These means are calculated from the sample used in the regressions. 
Table 5. Survival Regression

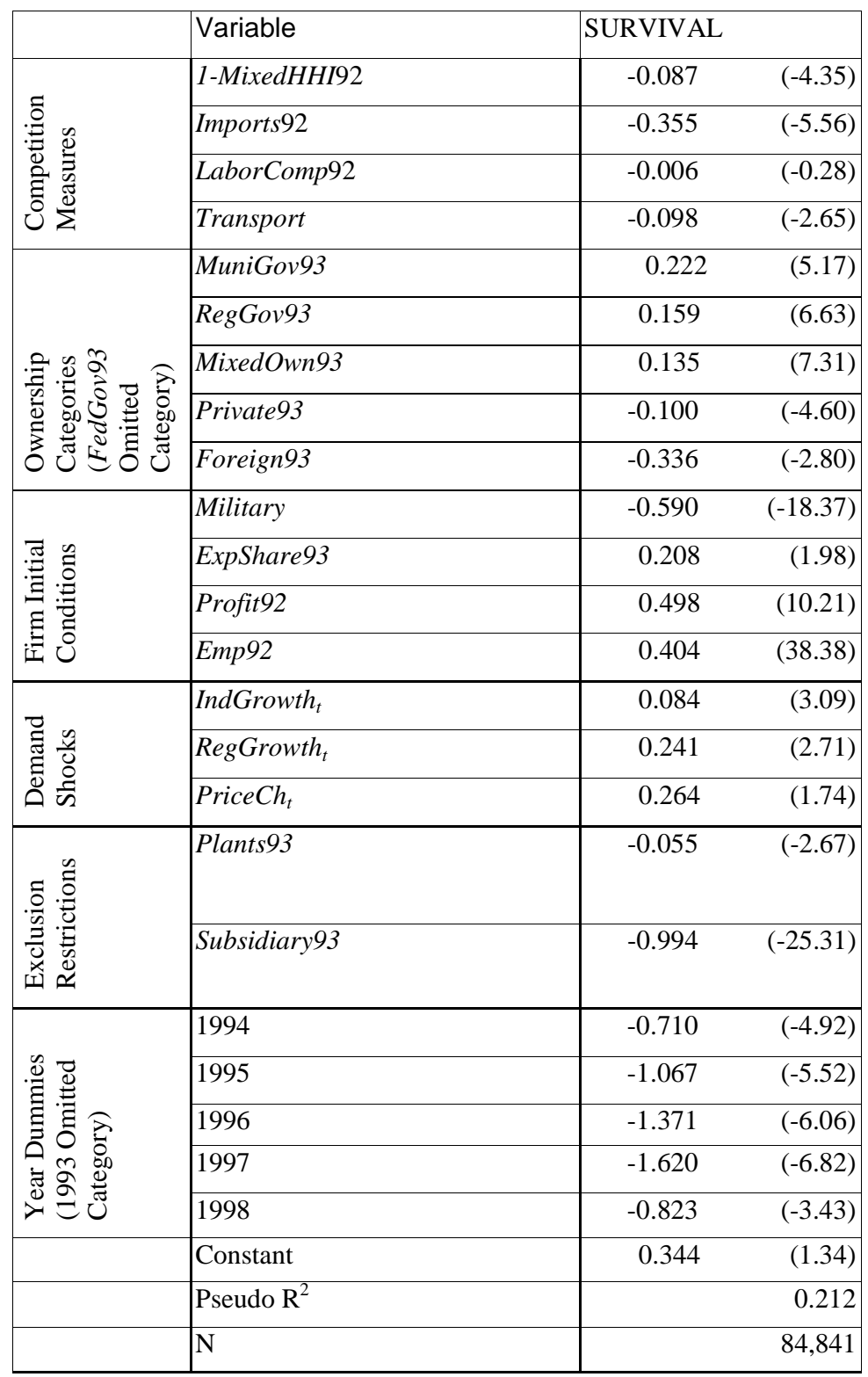

This is a pooled probit regression, where the dependent variable is a dummy for survival (i.e., with non-missing data in the given year), separately for survival in 1993, 1994, 1995, 1996, 1997, and 1998, respectively. ConShare, the consumer goods share of total output, and branch dummies are also included. The $\mathrm{z}$ statistics, using Huber/White/sandwich robust standard errors, are reported in parentheses. 
Table 6. Basic Regressions

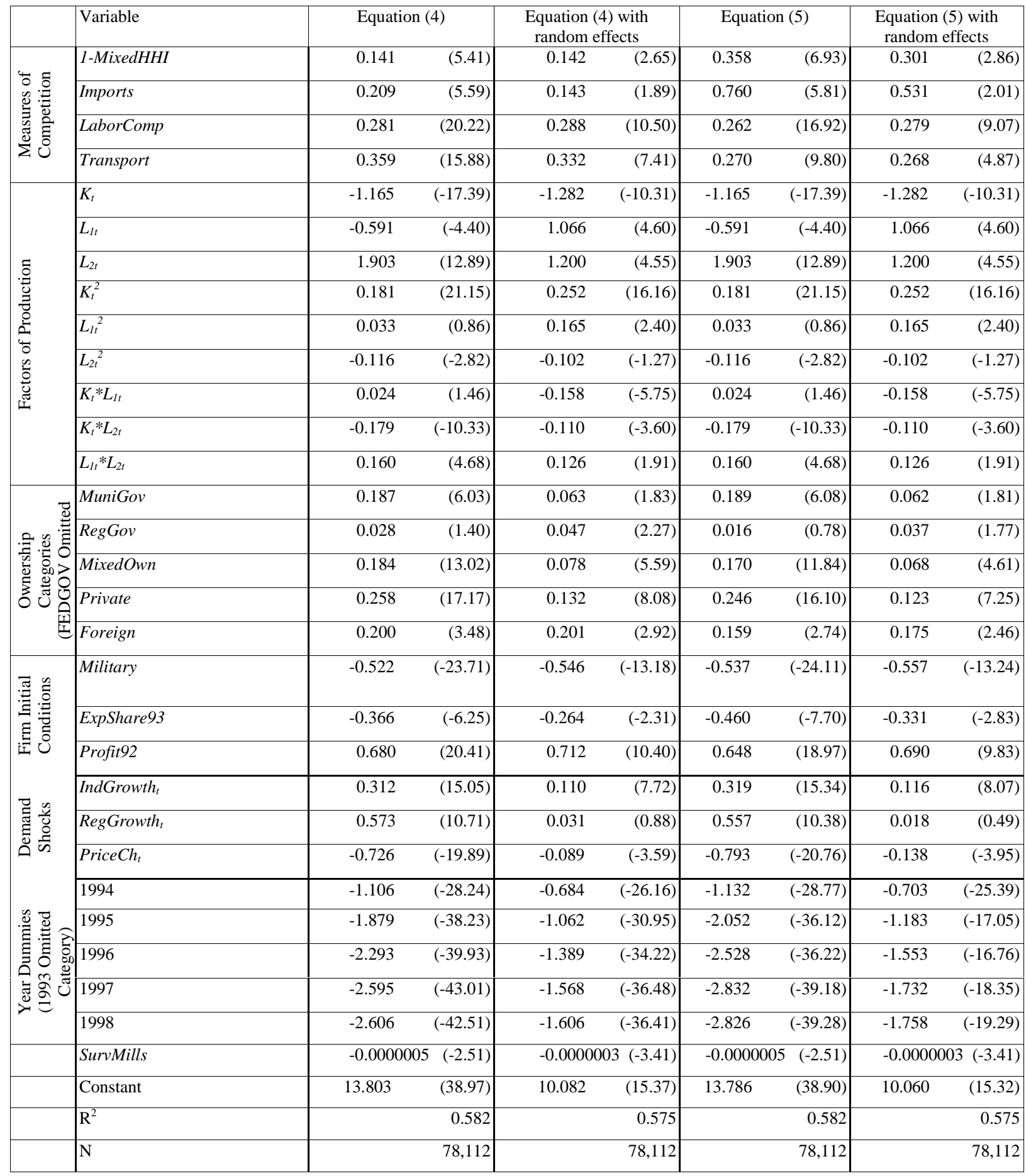

The $t$ statistics are reported in parentheses. They are based on White-corrected robust standard errors in the OLS specifications and they are adjusted for clustering on the same firms across time in the random effects specifications. ConShare and industry group dummies are also included. FedGov is the omitted ownership category. The marginal returns to $K_{t}, L_{1 t}$, and $L_{2 t}$ are $0.433,0.560$, and 0.131 , respectively, in the OLS regressions and $0.458,0.584$, and 0.130 in the random effects regressions. 
Table 7. The Effects of Competition on Performance Over Time

\begin{tabular}{|c|c|c|c|c|c|c|c|}
\hline & & 1993 & 1994 & 1995 & 1996 & 1997 & 1998 \\
\hline \multirow{8}{*}{ 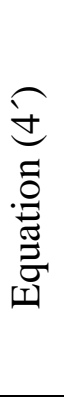 } & 1-MixedHHI & -0.075 & -0.055 & 0.099 & 0.233 & 0.245 & 0.260 \\
\hline & & $(-1.87)$ & $(-1.17)$ & $(1.91)$ & $(4.15)$ & $(3.97)$ & $(3.45)$ \\
\hline & Imports & 0.361 & 0.255 & 0.241 & 0.279 & 0.373 & 0.419 \\
\hline & & $(6.65)$ & $(3.67)$ & $(3.12)$ & $(3.27)$ & $(4.07)$ & $(4.01)$ \\
\hline & LaborComp & 0.339 & 0.326 & 0.279 & 0.240 & 0.253 & 0.329 \\
\hline & & (13.95) & $(10.75)$ & $(8.73)$ & $(7.21)$ & $(6.64)$ & $(6.80)$ \\
\hline & Transport & 0.273 & 0.395 & 0.422 & 0.284 & 0.178 & 0.427 \\
\hline & & $(6.60)$ & $(7.62)$ & $(7.76)$ & $(4.88)$ & $(2.82)$ & $(5.77)$ \\
\hline \multirow{8}{*}{ 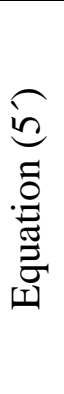 } & 1-MixedHHI & 0.153 & 0.137 & 0.338 & 0.448 & 0.460 & 0.509 \\
\hline & & $(2.66)$ & $(2.16)$ & $(4.99)$ & $(6.20)$ & $(5.94)$ & $(5.66)$ \\
\hline & Imports & 1.191 & 0.899 & 0.969 & 0.844 & 0.913 & 1.081 \\
\hline & & $(9.05)$ & $(6.67)$ & $(7.06)$ & $(6.00)$ & $(6.33)$ & $(7.15)$ \\
\hline & LaborComp & 0.313 & 0.314 & 0.262 & 0.227 & 0.235 & 0.308 \\
\hline & & $(12.20)$ & $(9.87)$ & $(7.78)$ & $(6.48)$ & $(5.91)$ & $(6.07)$ \\
\hline & Transport & 0.163 & 0.327 & 0.344 & 0.223 & 0.104 & 0.327 \\
\hline & & $(3.79)$ & $(6.12)$ & $(6.16)$ & $(3.74)$ & (1.61) & $(4.32)$ \\
\hline
\end{tabular}

The t statistics, using White-corrected robust standard errors, are reported in parentheses. All other variables in the basic Equation (4) reported in column 1 of Table 6 are also included. These regressions use a balanced panel of 10,237 enterprises with data in all years, adding to 61,422 total observations. The $\mathrm{R}^{2}$ in both regressions is 0.598 .

Table 8. Non-Linear Effects of Competition on Performance

\begin{tabular}{|l|rr|rr|}
\hline Competition Variable & \multicolumn{3}{|c|}{ Equation (4) } & \multicolumn{2}{|c|}{ Equation (5) } \\
\hline 1-MixedHHI & -0.249 & $(-2.84)$ & 0.007 & $(0.06)$ \\
\hline (1-MixedHHI $)^{2}$ & 0.371 & $(4.09)$ & 0.370 & $(4.08)$ \\
\hline Imports & 0.362 & $(8.76)$ & 1.162 & $(8.38)$ \\
\hline Imports $^{2}$ & -0.512 & $(-4.92)$ & -0.484 & $(-4.69)$ \\
\hline LaborComp & 0.019 & $(0.23)$ & -0.033 & $(-0.38)$ \\
\hline LaborComp $^{2}$ & 0.269 & $(3.41)$ & 0.268 & $(3.40)$ \\
\hline Transport $^{2}$ & -0.207 & $(-2.01)$ & -0.334 & $(-3.19)$ \\
\hline Transport $^{2}$ & 0.513 & $(5.74)$ & 0.513 & $(5.74)$ \\
\hline
\end{tabular}

The t statistics, using White-corrected robust standard errors, are reported in parentheses. All other variables in the basic Equation (4) reported in column 1 of Table 6 are also included. 
Table 9. Robustness Checks

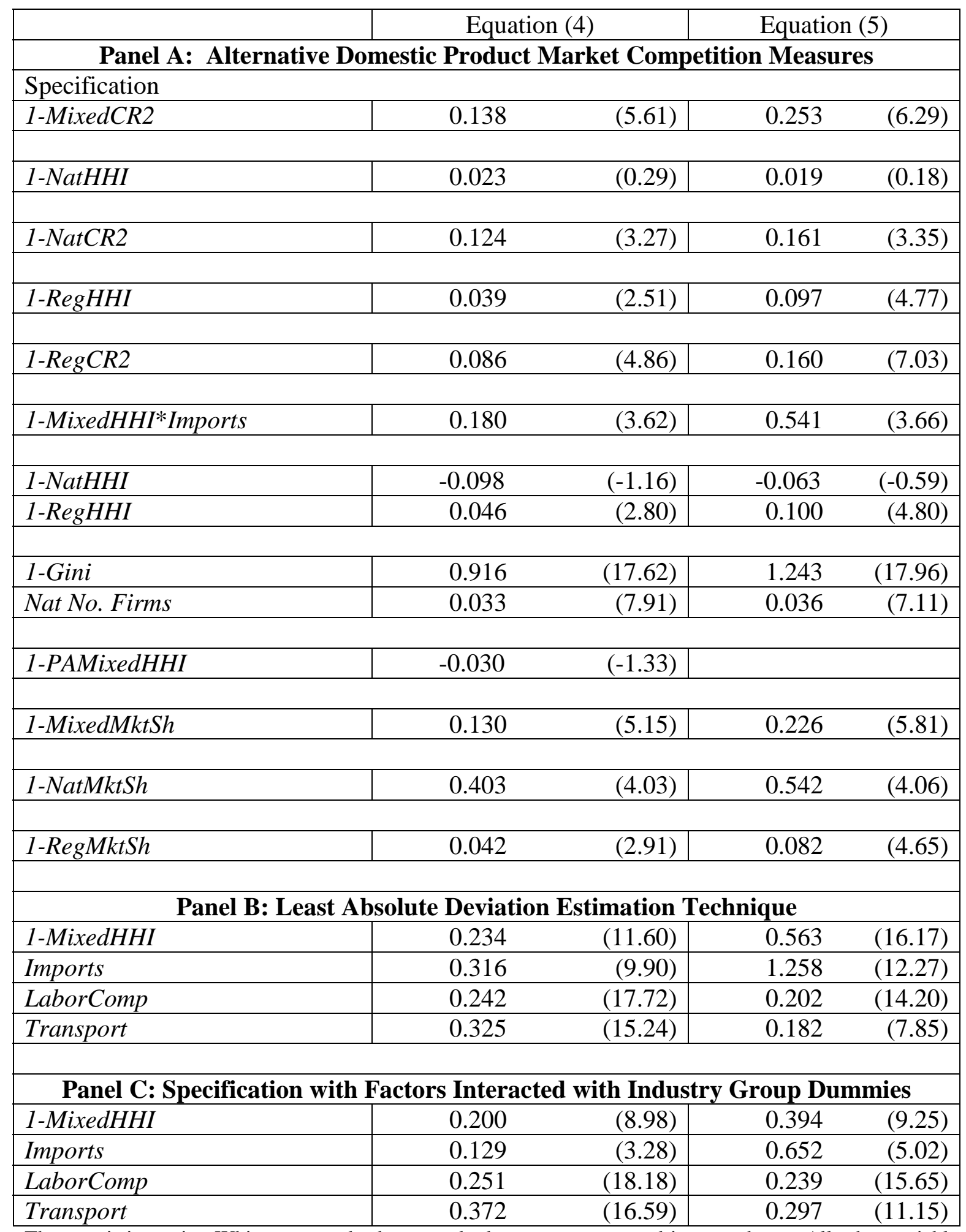

The t statistics, using White-corrected robust standard errors, are reported in parentheses. All other variables in the basic Equation (4) reported in column 1 of Table 6 are also included. The HHI*Imports specification does not include Imports by itself and the regional specifications do not include Transport. 
Table 10. Competition and Transportation Infrastructure Quality

\begin{tabular}{|c|c|c|c|c|}
\hline Variable & Equatic & & \multicolumn{2}{|c|}{ Equation (5) } \\
\hline \multicolumn{5}{|c|}{ Interacting Transport with Competition Measures } \\
\hline 1-MixedHHI & -0.100 & $(-1.95)$ & 0.203 & $(3.01)$ \\
\hline 1-MixedHHI *Transport & 0.675 & $(5.33)$ & 0.449 & $(3.37)$ \\
\hline Imports & 0.079 & $(1.09)$ & 0.963 & $(7.08)$ \\
\hline Imports*Transport & 0.345 & $(2.18)$ & -0.515 & $(-4.89)$ \\
\hline LaborComp & 0.375 & $(12.60)$ & 0.355 & $(11.12)$ \\
\hline LaborComp*Transport & -0.276 & $(-3.61)$ & -0.273 & $(-3.38)$ \\
\hline Transport & 0.027 & $(0.19)$ & 0.294 & $(2.00)$ \\
\hline \multicolumn{5}{|c|}{ Using Transport to Define Market Size: HHI } \\
\hline 1-TransportMixedHHI & 0.100 & $(4.82)$ & 0.170 & $(6.90)$ \\
\hline \multicolumn{5}{|c|}{ Using Transport to Define Market Size: CR2 } \\
\hline 1-TransportMixedCR2 & 0.201 & $(9.75)$ & 0.269 & $(11.38)$ \\
\hline
\end{tabular}

The t statistics, using White-corrected robust standard errors, are reported in parentheses. All other variables in the basic Equation (4) reported in column 1 of Table 6 are also included, with the exception of Transport in the latter two specifications (due to collinearity with the mixed transport competition measures). 
Table 11. Ownership Effects

\begin{tabular}{|c|c|c|c|c|c|c|c|c|c|}
\hline & & \multicolumn{2}{|c|}{ OLS } & \multicolumn{2}{|c|}{ OLS with Selection Correction } & \multicolumn{2}{|c|}{ Random Effects } & \multicolumn{2}{|c|}{$\begin{array}{c}\text { Random Effects with Selection } \\
\text { Correction }\end{array}$} \\
\hline \multirow{7}{*}{ 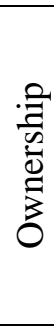 } & Non-State & $0.190(16.67)$ & & $0.036 \quad(1.68)$ & & $0.076(6.26)$ & & $0.054 \quad(2.55)$ & \\
\hline & & & & & & & & & \\
\hline & MuniGov & & $0.187 \quad(6.03)$ & & $\begin{array}{ll}0.371 & (9.02) \\
\end{array}$ & & $0.063 \quad(1.83)$ & & $0.140 \quad(2.90)$ \\
\hline & RegGov & & $0.028 \quad(1.40)$ & & $0.253 \quad(7.44)$ & & $0.047 \quad(2.27)$ & & $0.149 \quad(4.18)$ \\
\hline & MixedOwn & & $0.184(13.02)$ & & $0.104 \quad(3.70)$ & & $\begin{array}{ll}0.078 & (5.59)\end{array}$ & & $-0.006 \quad(-0.21)$ \\
\hline & Private & & $0.258(17.17)$ & & $0.163 \quad(6.25)$ & & $0.132 \quad(8.08)$ & & $0.065 \quad(2.25)$ \\
\hline & Foreign & & $0.200 \quad(3.48)$ & & $0.315 \quad(4.79)$ & & $0.201 \quad(2.92)$ & & $0.202 \quad(2.67)$ \\
\hline \multirow{9}{*}{  } & Non-State & & & $-0.010(-6.07)$ & & & & $-0.002(-1.52)$ & \\
\hline & State & & & $0.234 \quad(9.51)$ & & & & $0.035 \quad(1.43)$ & \\
\hline & & & & & & & & & \\
\hline & MuniGov & & & & $\begin{array}{ll}0.018 \quad(0.41) \\
\end{array}$ & & & & $-0.005(-0.14)$ \\
\hline & RegGov & & & & $-0.036 \quad(-1.58)$ & & & & $-0.027(-1.22)$ \\
\hline & FedGov & & & & $0.205(13.84)$ & & & & $0.067 \quad(4.47)$ \\
\hline & MixedOwn & & & & $0.206(15.06)$ & & & & $0.114 \quad(8.01)$ \\
\hline & Private & & & & $0.311(19.30)$ & & & & $0.138 \quad(7.20)$ \\
\hline & Foreign & & & & $\begin{array}{ll}0.663 & (3.88)\end{array}$ & & & & $0.352 \quad(2.32)$ \\
\hline
\end{tabular}

The t statistics, using White-corrected robust standard errors, are reported in parentheses. The omitted ownership category in the aggregated specification is state ownership and the omitted category in the disaggregated specification is federal state ownership. All other variables in the basic Equation (4) reported in column 1 of Table 6 are also included. 

